\title{
Quantitative and qualitative differences in morphological traits of endocarps revealed between Cornus L. species
}

\author{
Agata Woźnicka · Iwona Melosik • Maria Morozowska
}

Received: 6 August 2013/Accepted: 2 May 2014/Published online: 5 June 2014

(c) The Author(s) 2014. This article is published with open access at Springerlink.com

\begin{abstract}
The genus Cornus encompasses a wide range of attractive wild taxa, often used as ornamental plants in landscaping. The aim of this investigation was to highlight the quantitative and qualitative diversity within endocarp morphological traits apparent among 15 Cornus species representing different geographical and phylogenetic groups. Seventeen morphological traits of Cornus endocarps were evaluated in 185 Cornus collections originating from the Northern Hemisphere. To explore structure in our dataset and reduce its complexity, several multivariate statistical analyses (i.e., PCA, MANOVA, ANOVA, and analysis of contingency tables) were employed. Two clearly distinct sample groups were observed after the PCA, reflecting a high level of taxonomic division of analyzed species, i.e., subgenera: Mesomora and Kraniopsis. The study highlights qualitative and/or quantitative characters that partitioned (1) groups of species or some individual species, (2) geographical groups, and (3) cultivated and wild collections. Results of trait validation are presented in identification keys. A partial congruence was detected between our results and a currently available species level phylogeny of the genus Cornus. The
\end{abstract}

Electronic supplementary material The online version of this article (doi:10.1007/s00606-014-1073-1) contains supplementary material, which is available to authorized users.

A. Woźnicka · M. Morozowska

Department of Botany, Poznań University of Life Sciences,

Wojska Polskiego Str. 71c, 60-625 Poznań, Poland

I. Melosik $(\bowtie)$

Department of Genetics, Adam Mickiewicz University

in Poznań, Umultowska Str. 89, 61-614 Poznań, Poland

e-mail: melosik1@amu.edu.pl morphology of Cornus endocarps is of taxonomic importance and provides a key for species identification. The existence of only subtle morphological differences between some closely related taxa does not sufficiently explain their species status. The applicability of our results to the previously published morphological records is limited, mainly due to vague terminology. Considerably more work will need to be done to determine the effect of cultivation on qualitative reproductive traits of Cornus species.

Keywords Blue- or white-fruited dogwoods - Cornus . Endocarp morphology · ANOVA · MANOVA .

Principal component analysis

\section{Introduction}

Cornus L. consists of 58 species that are mostly shrubs, small trees, or, rarely, perennial herbs with woody rhizomes. The centers of the generic diversity are East Asia and North America with the exception of two species in South America and one in tropical East Africa (Wangerin 1910; Macbride 1929; Eyde 1988; Stevens 2012).

Due to the considerable morphological, cytological and biochemical heterogeneity of dogwoods, many contributions concerning the classification of taxa to groups of different affinity have been published (e.g. Wangerin 1910; Hutchinson 1942; Pojarkova 1950; Ferguson 1966; Eyde 1987; Xiang 1987; Murrell 1993, 1996; Hardin and Murrell 1997; Takhtajan 1997; Feng et al. 2011). In the current classification, dogwoods are divided into four major clades: the blue- or white-fruited (BW, 35-45 species), the cornelian cherries (CC, 6 species), the big-bracted (BB, $\sim 7-12$ species), and the dwarf dogwoods (DD 3 herbaceous species) (Xiang et al. 1993, 1996, 1998, 2006; 
Fan and Xiang 2001). The blue- or white-fruited dogwoods clade includes three subgenera: Yinquania (Zhu) Murrell, Kraniopsis Raf., and Mesomora Raf.

To date, there has been little agreement on the number of species and lower taxonomic ranks within the largest subgenus of dogwoods Kraniopsis (Xiang 1989; Murrell 1993; Xiang et al. 1996, 2006; Xiang and Boufford 2005). However, the taxonomic rank of species belonging to the subg. Mesomora has never been in doubt. This subgenus includes just two species that have alternate leaves: one is native to the subtropical and temperate regions of East Asia while the other is located in eastern North America.

In general, reproductive structures are important diagnostically. The taxonomic value of fruit morphology has already been recognized for many angiosperm families (Ronse Decraene et al. 2000; Padgett 2003; Bojňanský and Fargašová 2007; Toma 2008; Zarafshar et al. 2010; Morozowska et al. 2012). A high diversity of fruit and seed structures may provide some important insights for understanding a phylogeny of different angiosperm groups (Oh et al. 2008; Manchester et al. 2010).

The structure of endocarps and other traits related to vegetative and floral organs of Cornus were studied by Koehne (1903) and Wangerin (1910), who characterized up to $80 \%$ of all the described Cornus species from the Northern Hemisphere that are known to science. Later, a series of studies was undertaken to improve the quality of the earlier conclusion regarding the systematic of this genus (e.g., Fosberg 1942; Wilson 1965; Eyde 1987, 1988; Murrell 1993; Takhtajan 1997; Xiang et al. 2003; Kubitzki 2004; Xiang and Boufford 2005; Bojňanský and Fargašová 2007; Manchester et al. 2010; Schulz 2011, 2012). Some authors (Eyde 1988; Manchester et al. 2010) do have some grounds to think that fossil dogwood fruits, especially those preserved intact in brown coal beds, are taxonomically useful and often can serve to identify the major clades (BW, BB, CC, DD) or a group of species within a particular subgenera. As stated by Eyde (1988), Cornus endocarp can be identified by its germination valves. Other features, such as endocarp size, its symmetry, shape of its apical or basal portions, variation in the occurrence of apical pit, surface sculpturing (e.g., ribs, furrows, grooves, vascular bundles), and features of its histology can be evaluated to facilitate identification to the lower taxonomic ranks within the genus. However, considering fossils representing taxa of the BW clade, many of these traits overlap and may have limited usefulness in taxonomic practice. Nevertheless, the fossil endocarps with the conspicuous apical depression and branched grooves on the outer surface may be linked to the existing Cornus alternifolia L.f. and C. controversa Hemsl. from subg. Mesomora. Moreover, some features of the endocarp sculpture (ribbing pattern) allow for a simple identification of Nyssa, a genus closely related to Cornus (Eyde 1997).
In the most comprehensive and recent study done by Schulz (2012), within the subg. Kraniopsis, a description (with interpretation or links to other research) has been provided for 30 entities of different taxonomic rank, including cultivars, species that have an ambiguous taxonomic position, and so-called "good species". Endocarps of these taxa have been considered in terms of their dimensions, overall shape variations, shape of basal and apical parts, and surface ribbing intensity. Based on features related to vegetative and floral organs and endocarp traits, a revision of the Cornus species has been proposed. Some species are highly variable in analyzed traits and so were reduced to the rank of subspecies or variety: C. alba ssp. stolonifera (Michx.) Wangerin, C. asperifolia var. drummondii (C.A. Mey.) J.M. Coult. \& W.H. Evans, C. amomum ssp. obliqua (Raf.) J.S. Wilson, and C. sanguinea ssp. australis (C.A. Mey.) Jáv.

Here, we evaluate the taxonomic value of 17 morphological traits of endocarps among 15 currently accepted Cornus species in subg. Kraniopsis and Mesomora. The goal of these studies is to extend our information concerning the comparative morphology of Cornus endocarps and reevaluate their taxonomic significance predominantly in the blue- or white-fruited group.

These species have been extensively investigated by Xiang et al. (1993, 1996, 1998, 2006), Xiang and Boufford (2005), and Schulz $(2011,2012)$ using different molecular methods and the classical taxonomic approach. According to Xiang et al. (2006), three subclades were recognized within subg. Kraniopsis: subclade I, which consists of North American species; subclade II, which contains species from boreal Eurasia, North America, and East Asia; and subclade III, which is represented by a few East Asian species. Because of these differences, we were also trying to answer the following question: Do species differ by geography in terms of endocarp morphology?

The geographic distribution and range of species' habitats are expanded by humans through displacement and cultivation in arboreta and botanical gardens as well as other introductions (Miller and Knouft 2006). Relaxed selective pressure in culture conditions due to the clearing of competing plants, sufficient water supply, and genetic drift may result in morphological, physiological, and genetic changes in cultivated populations that make them significantly distinct from wild populations (e.g., Anthony et al. 2002; Miller and Knouft 2006). Quantitative methods for the evaluation of morphological and physiological traits in wild and cultivated populations of various plants were undertaken previously (Paz and Vázquez-Yanes 1998 and references therein, see also: Fleming and Valiente-Banuet 2002; Chang et al. 2011; Wang et al. 2012). In our study, the availability of wild and cultivated Cornus collections provided us the opportunity to visualize trends of morphological differentiation influenced by human versus 
Table 1 Summary of wild (w) and cultivated (c) specimens of Cornus species native to North America and Eurasia, number of specimens, and number of endocarps examined

\begin{tabular}{|c|c|c|c|c|c|c|c|c|c|c|c|c|c|c|c|c|c|}
\hline \multirow[t]{2}{*}{ Cornus species } & \multicolumn{16}{|c|}{ Specimen } & \multirow[b]{2}{*}{$\begin{array}{l}\text { Number of } \\
\text { endocarps }\end{array}$} \\
\hline & & 1 & 2 & 3 & 4 & 5 & 6 & 7 & 8 & 9 & 10 & 11 & 12 & 13 & 14 & 15 & \\
\hline \multicolumn{18}{|l|}{ North American } \\
\hline \multirow[t]{2}{*}{ alternifolia } & $\mathrm{w}$ & 5 & 5 & 2 & 3 & 5 & 10 & & & & & & & & & & 30 \\
\hline & c & 30 & 30 & 30 & 30 & 30 & 10 & & & & & & & & & & 160 \\
\hline \multirow[t]{2}{*}{ атотит } & $\mathrm{w}$ & 5 & 5 & 6 & 10 & & & & & & & & & & & & 26 \\
\hline & c & 30 & 30 & 30 & 30 & 30 & 30 & & & & & & & & & & 180 \\
\hline \multirow[t]{2}{*}{ drummondii } & $\mathrm{w}$ & 5 & 4 & 5 & 6 & 5 & 5 & & & & & & & & & & 30 \\
\hline & c & 30 & 30 & 30 & 30 & 30 & 30 & & & & & & & & & & 180 \\
\hline \multirow[t]{2}{*}{ foemina } & $\mathrm{w}$ & 5 & 5 & 5 & 5 & 6 & 6 & 6 & & & & & & & & & 38 \\
\hline & c & 30 & 30 & 30 & & & & & & & & & & & & & 90 \\
\hline \multirow[t]{2}{*}{ obliqua } & $\mathrm{w}$ & 6 & 5 & 5 & 7 & 8 & & & & & & & & & & & 31 \\
\hline & c & 30 & 30 & 30 & 30 & 30 & & & & & & & & & & & 150 \\
\hline \multirow[t]{2}{*}{ occidentalis } & $\mathrm{w}$ & 5 & 3 & 3 & 5 & 5 & 4 & 3 & 6 & & & & & & & & 34 \\
\hline & c & 30 & 30 & 30 & & & & & & & & & & & & & 90 \\
\hline \multirow[t]{2}{*}{ racemosa } & $\mathrm{w}$ & 5 & 5 & 6 & 5 & 7 & 5 & & & & & & & & & & 33 \\
\hline & c & 30 & 30 & 30 & 30 & 30 & 30 & & & & & & & & & & 180 \\
\hline \multirow[t]{2}{*}{ sericea } & $\mathrm{w}$ & 7 & 5 & 3 & 5 & 5 & 5 & 5 & 3 & 5 & 5 & & & & & & 48 \\
\hline & c & 30 & 30 & 30 & 30 & 30 & 30 & & & & & & & & & & 180 \\
\hline \multicolumn{18}{|l|}{ Eurasian } \\
\hline \multirow[t]{2}{*}{$a l b a$} & $\mathrm{w}$ & 5 & 5 & 5 & 5 & 6 & 17 & 30 & 18 & 22 & 12 & & & & & & 125 \\
\hline & $\mathrm{c}$ & 30 & 30 & 30 & 30 & 30 & & & & & & & & & & & 150 \\
\hline \multirow[t]{2}{*}{ australis } & $\mathrm{w}$ & 3 & 5 & 5 & 5 & 5 & 5 & 5 & 5 & 5 & 6 & 6 & 5 & 5 & 4 & 30 & 99 \\
\hline & $\mathrm{c}$ & 30 & 30 & 30 & 30 & 20 & & & & & & & & & & & 140 \\
\hline bretschneideri & $\mathrm{c}$ & 30 & 30 & 30 & & & & & & & & & & & & & 90 \\
\hline \multirow[t]{2}{*}{ controversa } & $\mathrm{w}$ & 5 & 5 & 11 & 3 & 5 & 5 & 3 & 3 & & & & & & & & 40 \\
\hline & $\mathrm{c}$ & 30 & 30 & 30 & 30 & 30 & 30 & & & & & & & & & & 180 \\
\hline \multirow[t]{2}{*}{ macrophylla } & $\mathrm{w}$ & 5 & 10 & 5 & & & & & & & & & & & & & 20 \\
\hline & $\mathrm{c}$ & 30 & 30 & 30 & & & & & & & & & & & & & 90 \\
\hline \multirow[t]{2}{*}{ sanguinea } & $\mathrm{w}$ & 5 & 5 & 5 & 5 & 5 & 6 & 5 & 5 & 5 & 5 & 5 & 4 & 4 & 8 & 5 & 77 \\
\hline & $\mathrm{c}$ & 30 & 30 & 30 & 30 & 30 & 30 & & & & & & & & & & 180 \\
\hline \multirow[t]{2}{*}{ walteri } & $\mathrm{w}$ & 5 & 5 & 5 & 6 & 6 & 2 & 3 & 4 & 2 & & & & & & & 38 \\
\hline & $\mathrm{c}$ & 30 & 30 & 30 & 13 & & & & & & & & & & & & 103 \\
\hline \multirow[t]{2}{*}{ Total } & $\mathrm{w}$ & & & & & & & & & & & & & & & & 669 \\
\hline & $\mathrm{c}$ & & & & & & & & & & & & & & & & 2,143 \\
\hline
\end{tabular}

natural selection or/and random changes between those two types of materials. Thus, the paper is structured around questions related to Cornus taxonomy and its geography as well as the impact of cultivation on endocarp morphology.

\section{Materials and methods}

\section{Materials}

In spite of efforts being made, numerous fully developed fruits were available only for some of already described species from subg. Kraniopsis and Mesomora. The endocarps of Cornus species were supplied by 21 arboreta and botanical gardens (Online Resource 1). One hundred twelve wild-growing specimens representing 14 Cornus species were obtained from 13 herbaria: A, BM, G, GH, H, K, KOR, KRAM, L, LISU, S, SZCZ, WA, and two botanical gardens (Thiers, Index Herbariorum) or were collected by the first author (Online Resource 2). The cultivated specimens, selected according to their availability, were represented by 15 Cornus species. A composition of wild and cultivated species was almost fully congruent, with the exception of Cornus bretschneideri L. 
Fig. 1 Geographical locations of cultivated accessions analyzed in this study. a North America, b Europe, c Japan. For numbers see Table 1 , Supplementary materials

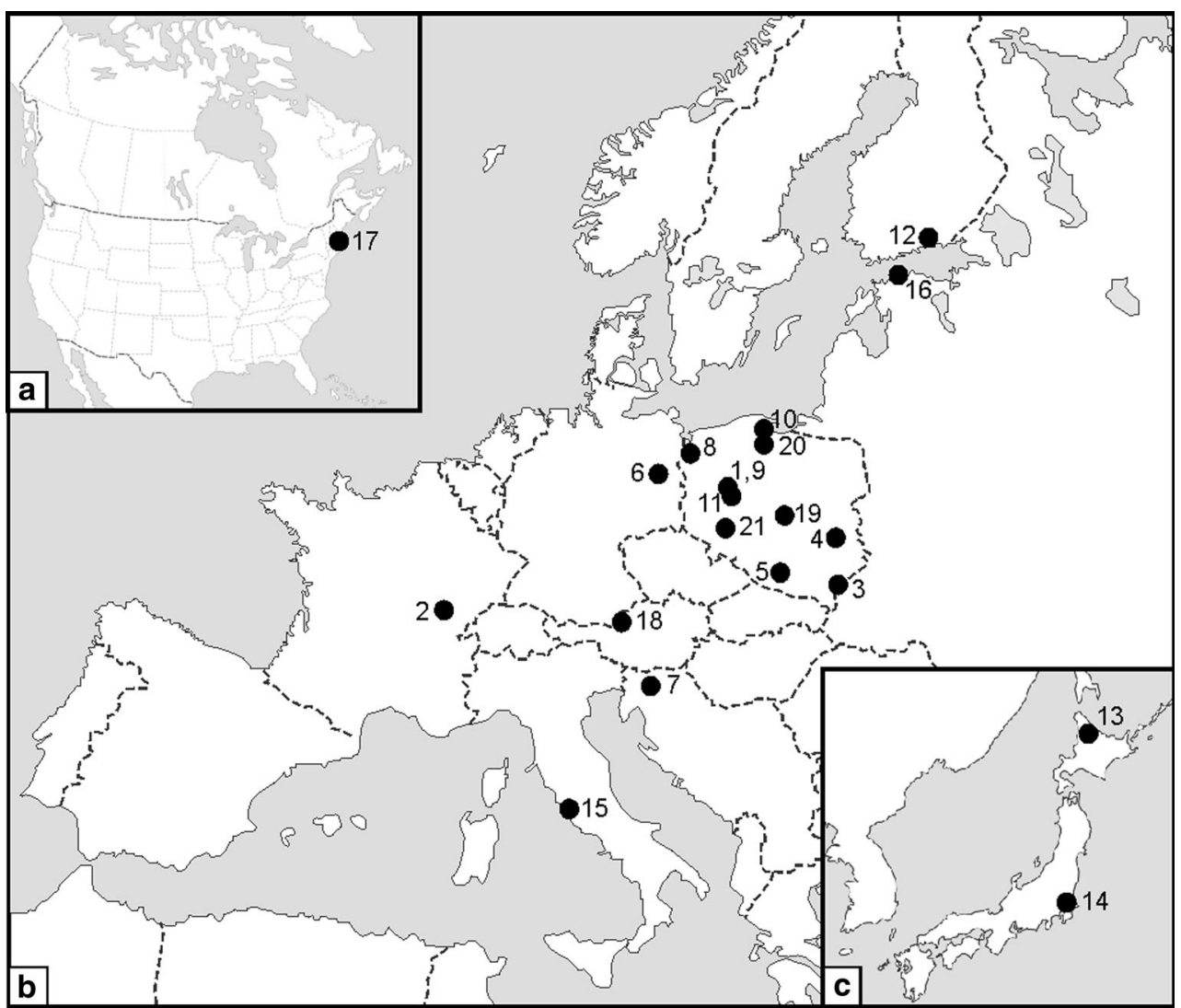

Henry for which only the cultivated materials were available (Table 1). A total of 2,812 endocarps from 185 specimens were evaluated. Each species was represented by three to 15 specimens. The number of evaluated endocarps per specimen ranged from two to 30 for wild materials and 10-30 for cultivated materials, depending on their availability (Table 1).

The included samples were collected from 2009 to 2012. We chose to get the samples between July and October to reflect the fruiting period of the given species. Geographic locations of cultivated and wild accessions were mapped onto a counter map of the Northern Hemisphere using Mappad v. 2.0 (Figs. 1, 2).

In our work, we treated the original Cornus species identifications as valid and reliable. To ensure accuracy in this study, more than $80 \%$ of examined samples were checked by the first author using morphological characters of leaves, flowers, and inflorescences (Online Resource 2, 3). Nomenclature of species follows that of The Plant List (2010). Version 1.

\section{Plant measurements}

After collection, the samples were prepared for morphological analyses by removing a fleshy part of the fruit from its endocarp, soaking it in a $3.0 \%$ aquatic solution of citric acid, boiling it in water, and cleaning it mechanically. The samples were measured according to 17 traits. The measured traits and their codes are presented in Table 2, Fig. 3. Of these features, seven were quantitative (1-7), two described ratios between traits (8-9), and eight were coded as binary or multistate (10-17) (Table 2).

The terminology for characters of endocarp surface is explained below; see also Eyde (1997). The endocarp surface (SSF) can be described as smooth or rough. The rough surface can be longitudinally furrowed and/or ribbed. The term "furrow" was used to describe a distinct wide channel located on the lateral faces of endocarp and dividing it along the vertical axis; here, its absence or presence was examined (DF). Conspicuous numerous ribs can run continuously (from the apex to the base) or irregularly, and then they do not reach the ends of the endocarp. Vascular bundles running on the ribs, between them, or on the flat surface of endocarps and visible as light yellowish or white vertical strips were considered in this study. The number of vascular bundles (VN) running uninterrupted from the apex to the base of the endocarp, the presence or absence of bifurcated vascular bundles, named here as forked (FV), and their proportion (FV in \%) were defined. In addition, the position of vascular bundles (VBP) on the endocarp surface was examined. The vascular bundles can be: (1) sunken between ribs, then located on the bottom of 

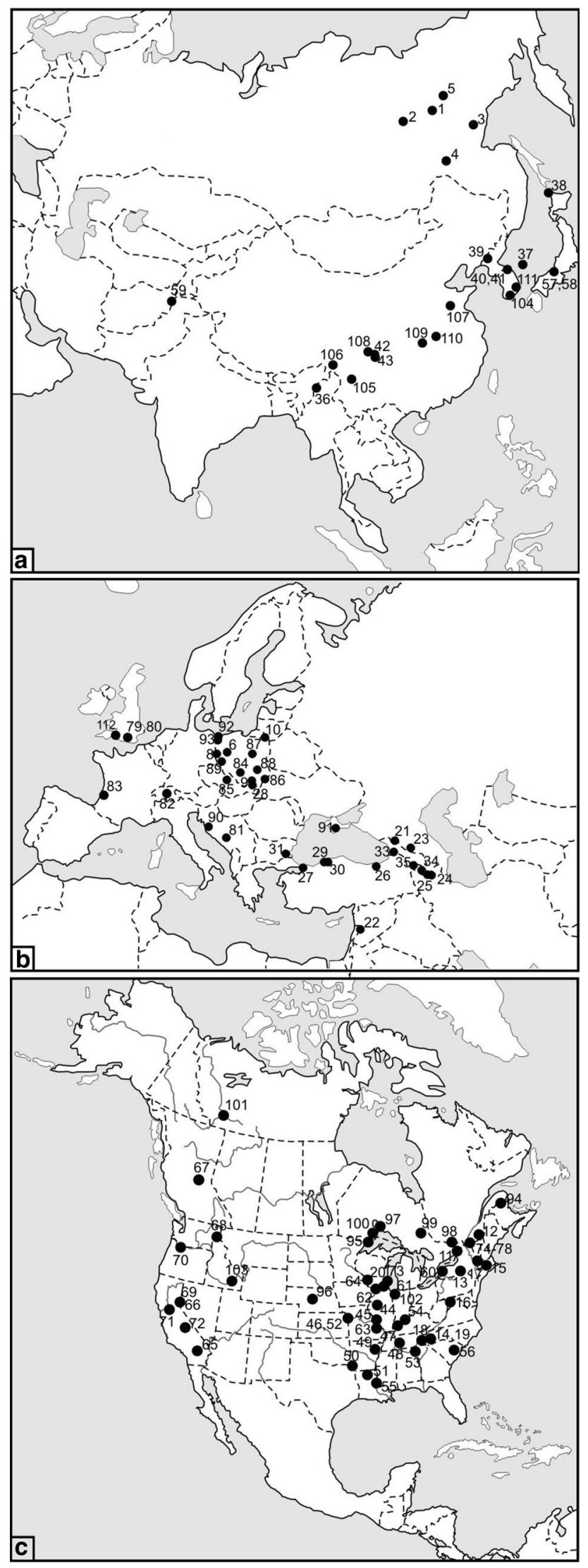

4Fig. 2 Geographical locations of wild-growing Cornus accessions analyzed in this study. a Asia, b Europe, c North America. For numbers see Table 2, Supplementary materials

longitudinal grooves (VBS); (2) flat (VBF), in this case the smooth surface is observed; or (3) raised, located on sharp crests of ribs (VBR). The rest of the traits coded as binary or multistate are described on Fig. 3.

\section{Data analysis}

For nine quantitative (continuous) variables, either measurements of endocarps $(2,812)$ or mean values for specimens (185) of pre-identified Cornus species were used. The quantitative variables were transformed to better approximate normality (Sárnal et al. 1999; Howell 2007; Tabachnick and Fidell 2007). Qualitative data are not normally distributed, so this set of data was considered separately.

To group a set of specimens into similar patterns, several univariate and multivariate statistical methods were employed. The principal component analysis (PCA) is a tool for data reduction. The PCAs were carried out to assess how many PC components should be considered in the analysis without any significant information loss, estimate the contribution of each variable to the analysis, and highlight the variation among endocarps by taking into account species affiliation. The PCA axes with eigenvalues greater than or near 1.0 were evaluated. For the first two/ three PC axes, scatterplots were presented.

A MANOVA based on the first PC scores was carried out to determine whether a separation of endocarps in terms of their taxonomic affiliation or origin was statistically significant. To evaluate this differentiation, each PC axis was compared by ANOVAs. To handle the multiple comparisons, the Bonferroni correction was used. PC scores were dependent variables, while taxonomic, geographic or another assignments were used as categorical variables.

For cultivated versus wild accessions, the PCA was carried out using different data sets based on mean values for all analyzed specimens, specimens representing species native to North America cultivated in Europe, and specimens representing species native to Asia cultivated in Europe. In all analyses, C. bretschneideri was excluded because only cultivated materials were obtained. To assess the quality of variances in cultivated and wild samples, the Levene's test was used. Specimens representing species native to North America and Asia cultivated in Europe were compared with those growing wild by taking quantitative traits into account. Equalized data sets were established for cultivated and wild materials. The PCA was also carried out for different data sets to assess the impact 
Table 2 Qualitative and quantitative characters used in morphometric analyses of Cornus endocarps, character abbreviations, respective character state assignments, and units of measurements

\begin{tabular}{|c|c|c|c|c|}
\hline No & Description & $\begin{array}{l}\text { Character } \\
\text { abbreviation }\end{array}$ & $\begin{array}{l}\text { Type of characters: } \\
\text { discrete (D) } \\
\text { continuous (C) }\end{array}$ & $\begin{array}{l}\text { Units of } \\
\text { measurements/ } \\
\text { coding }\end{array}$ \\
\hline 1 & Apical cavity length & ACL & $\mathrm{C}$ & $\mathrm{mm}$ \\
\hline 2 & Apical cavity width & $\mathrm{ACW}$ & $\mathrm{C}$ & $\mathrm{mm}$ \\
\hline 3 & Forked vascular bundles (\%) & $\mathrm{FV} \%$ & $\mathrm{C}$ & $\%$ \\
\hline 4 & Endocarp length & SL & $\mathrm{C}$ & $\mathrm{mm}$ \\
\hline 5 & Endocarp thickness & ST & $\mathrm{C}$ & $\mathrm{mm}$ \\
\hline 6 & Endocarp width & SW & $\mathrm{C}$ & $\mathrm{mm}$ \\
\hline 7 & $\begin{array}{l}\text { Number of vascular bundles } \\
\text { on endocarp surface }\end{array}$ & VN & $\mathrm{C}$ & \\
\hline 8 & $\begin{array}{l}\text { Ratio between endocarp length } \\
\text { and endocarp width }\end{array}$ & SL/SW & & \\
\hline 9 & $\begin{array}{l}\text { Ratio between endocarp width } \\
\text { and endocarp thickness }\end{array}$ & SW/ST & & \\
\hline 10 & Absence/presence of apical cavity & $\mathrm{ACP}$ & $\mathrm{D}$ & $0-1$ \\
\hline 11 & Absence/presence of distinctive furrow & DF & $\mathrm{D}$ & $0-1$ \\
\hline 12 & $\begin{array}{l}\text { Absence/presence of forked } \\
\text { vascular bundles }\end{array}$ & $\mathrm{FV}$ & $\mathrm{D}$ & $0-1$ \\
\hline 13 & Smooth/rough endocarp surface & SSF & $\mathrm{D}$ & $0-1$ \\
\hline 14 & Endocarp shape & SSH & $\mathrm{D}$ & $0-2$ \\
\hline 15 & Apical shape & ASH & $\mathrm{D}$ & $0-3$ \\
\hline 16 & Basal shape & BSH & $\mathrm{D}$ & $0-3$ \\
\hline 17 & $\begin{array}{l}\text { Vascular bundle position on the } \\
\text { endocarp surface }\end{array}$ & VBP & $\mathrm{D}$ & $0-2$ \\
\hline
\end{tabular}

of geography on endocarp morphology. Student's $t$ test was used for pairs of species/groups of species and trait(s).

For nominal discrete (qualitative) data, contingency tables were used to compute Pearson's Chi square test for independence. This test assessed the association between qualitative traits and the origin of specimens or species taxonomic assignment. Descriptive statistics were calculated for the quantitative variables of each species based on the entire data set. For qualitative variables, mode values were computed.

Based on the PCA results, contingency tables (Online Resources 10-13), descriptive statistics (Online Resources 14-15), and molecular analysis results provided by Xiang et al. (2006), separate dichotomous keys were constructed for species native to North America and Eurasia. Within each geographical group, a key for identification at the species group level was developed (bolded part of the key). Despite significant differences in endocarp morphological traits between species obtained for our analyses, these trait ranges overlap, making the separation of particular species difficult. Therefore the key for the identification at species level (not-bolded part of the key) permits to distinguish particular species with at least $75 \%$ certainty.

Data management and analyses were performed using the program STATISTICA 10 package, (StatSoft Inc.,
Tulsa, OK, USA), the Bonferroni correction was found at http:/quantitativeskills.com/sisa/calculations/bonfer.htm.

\section{Results}

Do cultivated specimens of Cornus species differ significantly in quantitative or qualitative endocarp traits from wild specimens?

A one-way MANOVA based on PC scores (Online Resource 4) with the origin of specimens as a categorical predictor variable showed insignificant differences in quantitative endocarp traits among these groups when all specimens were analyzed. This also occurred when wild specimens native to North America and those cultivated in Europe and wild specimens native to Asia and those cultivated in Europe were compared (Table 3). Cultivated and wild specimens appear to have equal variances for all quantitative traits (Table 4).

The Chi square test between qualitative traits and the origin of specimens belonging to species of subg. Mesomora and Kraniopsis did not show a significant relationship between analyzed traits and the specimen's origin (Table 5). Three traits, i.e. SSH, SSF, and ACP depend on 
Fig. 3 Graphical descriptions of measured endocarp traits: a Cornus controversa, bottom view (magnification $\times 5.0$ ); $\mathbf{b} C$. foemina, upper view $(\times 7.0)$; c $C$. sericea, bottom view (×6.8); d C. occidentalis, front view (×6.3); e C. obliqua, upper view $(\times 8.0)$; f C. obliqua, front view $(\times 7.0) ; \mathbf{g} C$. controversa, front view $(\times 5.4)$; h. C. alba, front view $(\times 7.5)$; i $C$. drummondii, front view $(\times 8.3)$ $A C L$ apical cavity length, $A C W$ apical cavity width, $A S H-O$ shortly acuminate apex, $A S H-1$ acuminate apex, $A S H-2$ bluntly acute or wedge-shaped apex, $A S H-3$ rounded or truncate apex, $B S H-O$ shortly acuminate base, $B S H$ - 1 long-acuminate base, $B S H-2$ rounded base, $B S H-3$ bluntly acute or wedgeshaped base, $D F$ distinctive furrow, $O$ presence, 1 absence, $F V$ forked vascular bundle, $S S H-O$ spherical $=$ globose endocarp shape, $\mathrm{SSH}-\mathrm{I}$ intermediate endocarp shape, $S S H-2$ flattened $=$ compressed endocarps shape, $S L$ endocarps length, $S T$ endocarps thickness, $S W$ endocarps width, $V B P-O$ sunken vascular bundles, $V B P-1$ flat vascular bundles, $V B P-2$ raised vascular bundles
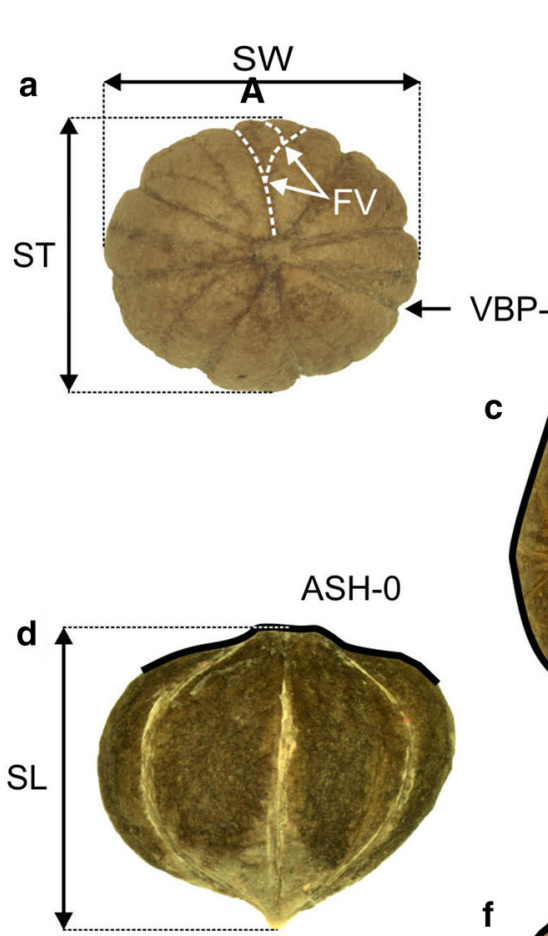

C

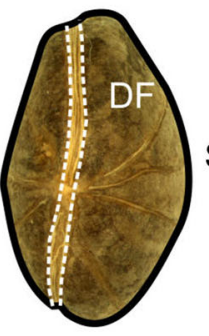

$\mathrm{SSH}-1$

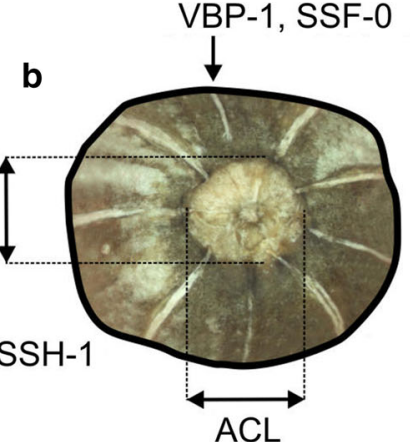

$\mathrm{SSH}-2$
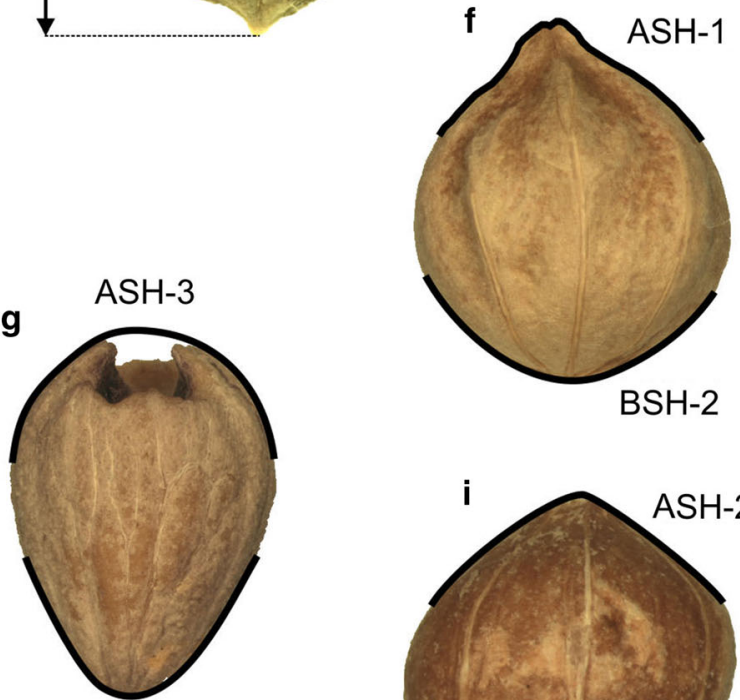

$\mathrm{BSH}-3$

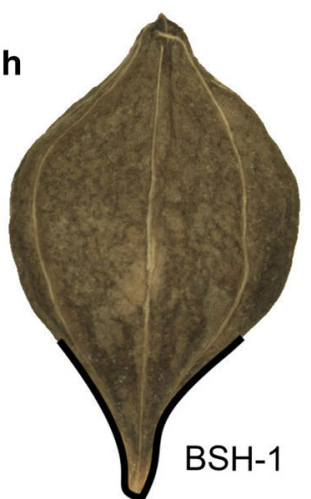

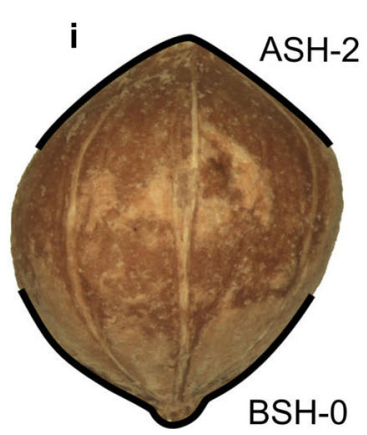

Table 3 Results of MANOVA based on PCA scores (dependent variables), and the origin of specimens (cultivated/wild) as a categorical variable for Cornus accessions: (1) all analyzed specimens, (2) specimens representing species native to North America cultivated in Europe, and (3) specimens representing species native to Asia cultivated in Europe

\begin{tabular}{lllllllll}
\hline & $N$ & All specimens & $P$ & $N$ & American species & $P$ & $N$ & Asian species \\
\hline MANOVA, & $N_{\mathrm{c}}=70 ;$ & 0.99 & 0.64 & $N_{\mathrm{c}}=40 ;$ & 0.99 & 0.83 & $N_{\mathrm{c}}=24 ;$ & 0.96 \\
Wilks Lambda & $N_{\mathrm{w}}=112$ & & & $N_{\mathrm{w}}=52$ & & & $N_{\mathrm{w}}=60$ & 0.37 \\
\hline
\end{tabular}


Table 4 Levene's test for equality of variances for continuous traits of Cornus endocarps, for specimens representing species native to North America and Asia growing wild and cultivated in Europe

\begin{tabular}{lllll}
\hline & $\begin{array}{l}\text { Species native to N. } \\
\text { America wild and } \\
\text { cultivated in Europe } \\
(N=40)\end{array}$ & & $\begin{array}{l}\text { Species native to Asia } \\
\text { wild and cultivated in } \\
\text { Europe } \\
(N=24)\end{array}$ \\
\cline { 2 - 3 } $\begin{array}{l}\text { Levene's } \\
\text { Trait }\end{array}$ & $F_{(1,79)}$ & $P$ & & $F_{(1,51)}$ \\
\hline SL & 1.35 & 0.25 & 5.34 & $P$ \\
SW & 0.64 & 0.42 & 1.13 & 0.02 \\
ST & 0.06 & 0.81 & 0.61 & 0.44 \\
SL/SW & 0.01 & 0.90 & 0.01 & 0.91 \\
SW/ST & 1.88 & 0.17 & 0.41 & 0.52 \\
VN & 1.87 & 0.17 & 4.31 & 0.04 \\
FV \% & 1.35 & 0.25 & 0.17 & 0.68 \\
ACL & 2.25 & 0.14 & 5.23 & 0.03 \\
ACW & 2.34 & 0.13 & 2.39 & 0.13 \\
\hline
\end{tabular}

For trait descriptions, see Table 2

Table 5 Results of Chi square test for independence between qualitative traits of endocarps and origin of specimens (cultivated vs. wild) for species belonging to subg. Mesomora and Kraniopsis (1) and subg. Kraniopsis (2)

\begin{tabular}{|c|c|c|c|c|c|}
\hline \multirow{2}{*}{$\begin{array}{l}\text { Subgenus } \\
\text { Trait }\end{array}$} & \multirow[b]{2}{*}{$d f$} & \multicolumn{2}{|l|}{1} & \multicolumn{2}{|l|}{2} \\
\hline & & Chi square & $P$ & Chi square & $P$ \\
\hline VBP & 2 & 3.22 & 0.20 & 2.68 & 0.10 \\
\hline BSH & 3 & 7.44 & 0.06 & 7.55 & 0.06 \\
\hline $\mathrm{ACP}$ & 1 & 3.47 & 0.06 & 4.40 & 0.04 \\
\hline DF & 1 & 2.37 & 0.12 & 3.15 & 0.07 \\
\hline SSF & 1 & 2.30 & 0.13 & 4.77 & 0.03 \\
\hline SSH & 2 & 1.44 & 0.49 & 7.15 & 0.03 \\
\hline ASH & 3 & 1.15 & 0.76 & 1.69 & 0.64 \\
\hline FV & 1 & 0.77 & 0.38 & 1.02 & 0.31 \\
\hline
\end{tabular}

Level of significance: $P<0.05$; For trait descriptions, see Table 2

the specimen's origin when only species of subg. Kraniopsis were analyzed.

Based on those results, we concluded that the subsequent analyses on quantitative traits should be performed on a combined data set of cultivated and wild materials while those based on qualitative traits are carried out on separated data sets.

Distinguishing pre-identified Cornus species based on quantitative and qualitative traits

Fifteen pre-identified species represented by 185 cultivated and wild specimens were analyzed using the PCA. The PCA produced three PC components with eigenvalues
Table 6 Results of principal component analysis on nine quantitative variables of Cornus endocarps based on cultivated and wild specimens representing species native to North America and Eurasia, $N=185$

\begin{tabular}{llll}
\hline Variable & Axis 1 & Axis 2 & Axis 3 \\
Eigenvalues & $\mathbf{3 . 6 3}$ & $\mathbf{1 . 8 1}$ & $\mathbf{1 . 4 0}$ \\
\hline Trait & \multicolumn{3}{c}{ Component loadings } \\
ACW & -0.84 & 0.18 & -0.37 \\
ACL & -0.84 & 0.18 & -0.37 \\
SW & -0.78 & -0.13 & -0.02 \\
ST & -0.77 & -0.36 & 0.48 \\
FV \% & -0.75 & 0.07 & -0.16 \\
SL & -0.53 & 0.60 & 0.45 \\
SW/ST & 0.37 & 0.43 & -0.64 \\
SL/SW & 0.17 & 0.79 & 0.49 \\
VN & 0.01 & -0.65 & 0.12 \\
Total variance explain. \% & $\mathbf{4 0 . 3 6}$ & $\mathbf{2 0 . 1 4}$ & $\mathbf{1 5 . 6 1}$ \\
Cumul. total variance explain. \% & $\mathbf{4 0 . 3 6}$ & $\mathbf{6 0 . 5 0}$ & $\mathbf{7 6 . 1 1}$ \\
\hline
\end{tabular}

For trait descriptions, see Table 2

The bold fonts were used to differentiate between: (1) the component loadings for a given set of traits and (2) eigenvalues associated with each principal component (how much variation in the data set it explains) and the total (or cumulative) variance explained

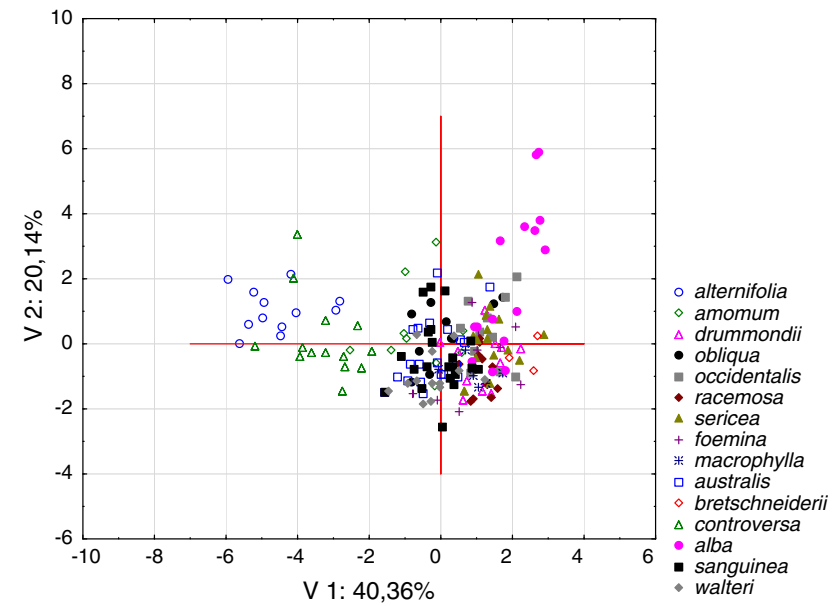

Fig. 4 Scatterplot of first two PCA components (V1, V2) for nine quantitative variables of endocarps based on mean values of 185 specimens representing 15 Cornus species

greater than 1.0 and a cumulative variance of $76.11 \%$ (Table 6). Using PCA scores as dependent variables and species assignment as a categorical variable, the one-way MANOVA shows significant differences among species (Wilks' lambda $=0.02, F_{(3,42)}=29.49, P<0.001$ ). The statistically significant separation among species occurs along all three PCA axes $\left(F_{(14,170)}=77.49,6.23\right.$, and 16.63, respectively, $P<0.001)$. 


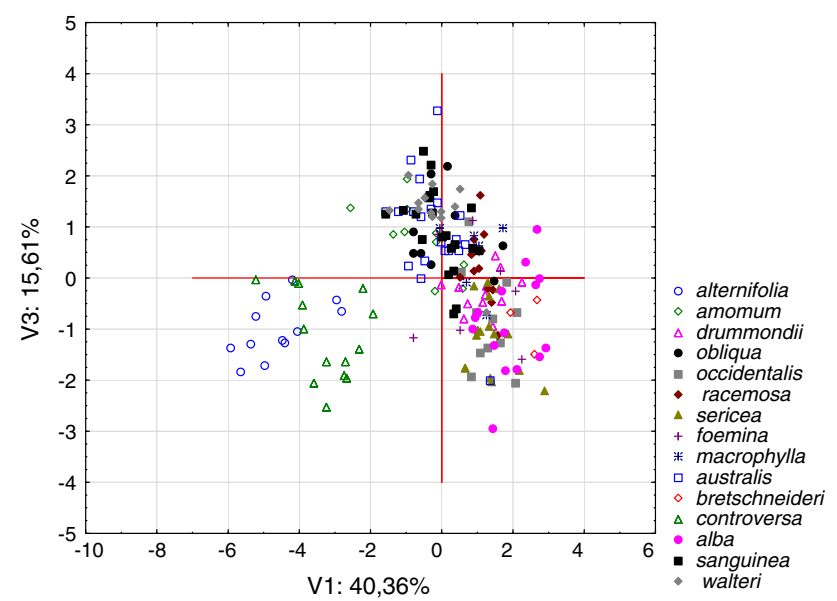

Fig. 5 Scatterplot of two PCA components (V1, V3) for nine quantitative variables of endocarps based on mean values of 185 specimens representing 15 Cornus species

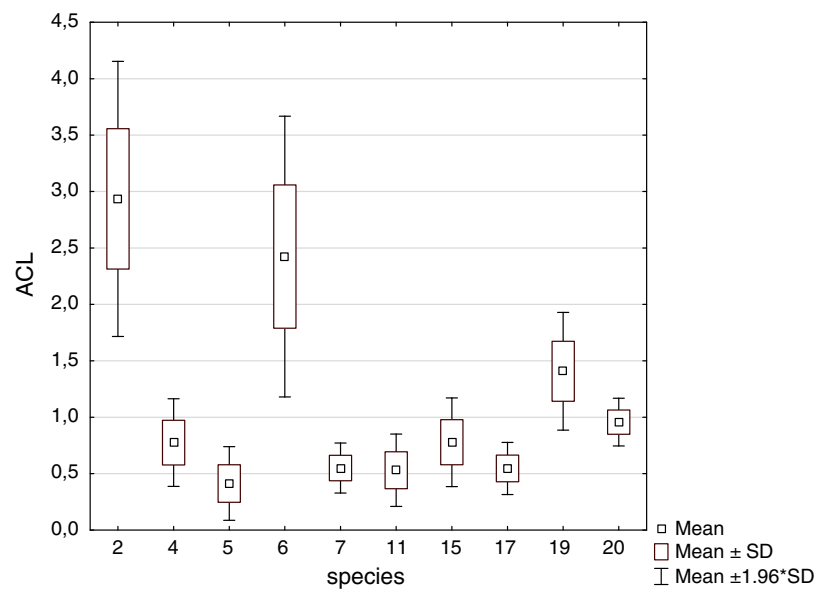

Fig. 6 Box-and-whisker plot for the length of apical cavity (ACL) situated at the apex of endocarps in 10 Cornus species. For names of species, see Table 7

The PCA analysis extracted some differences between the means for species belonging to subg. Mesomora and those in subg. Kraniopsis. There is, however, broad overlap among specimens of the latter (Figs. 4, 5).

The first PC component, which was $40.36 \%$ of total variation, indicated differences between species related to the apical cavity size (ACL, ACW). There was a significant difference between species of both subgenera (Student's $t$ test $=36.91$ and 42.20, for ACL and ACW, respectively, $d f=615, P<0.001)$. C. alternifolia and $C$. controvers $a$ of subg. Mesomora are characterized by a large apical cavity. These two species differ significantly from one another in the apical cavity size (ACL, ACW), and in the endocarp dimensions (SL and SW), (one-way MANOVA Wilks' lambda $\left.=0.15, F_{(9,16)}=10.2, P<0.0001\right)$. The means

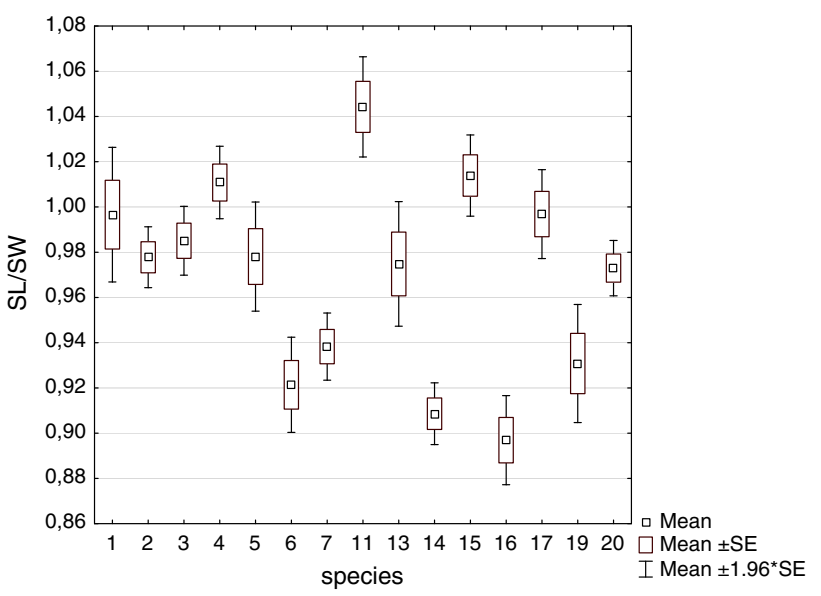

Fig. 7 Box-and-whisker plot for the ratio between endocarp length and endocarp width (SL/SW) in 15 Cornus species. For names of species, see Table 7

of these traits are larger in $C$. alternifolia than in $C$. controversa.

The apical cavity is usually absent in species of subg. Kraniopsis. If present, its size falls in the smaller range. That kind of apical depression occurs in the following species: C. australis C.A.Mey., C. bretschneideri, C. foemina Mill., C. macrophylla Wall., C. obliqua Raf., $C$. sanguinea L., and C. walteri Wangerin (Fig. 6). The lowest number of endocarps with apical depression was found in C. walteri $(7.7 \%)$, whereas the highest was in C. bretschneideri and C. macrophylla (33.3\%).

The separation on PCA axis 2, which was $20.14 \%$ of total variation, was caused mostly by the ratio between endocarp length and endocarp width (SL/SW). Nevertheless, no significant difference was detected between the mean trait value (SL/SW) for species of subg. Mesomora $(0.95[\mathrm{SD} \pm 0.14])$ and species of subg. Kraniopsis $(0.97$ $[\mathrm{SD} \pm 0.15]),(t$ test $=-1.71, d f=184, P<0.09)$. A group of species $C$. alternifolia, $C$. controversa, $C$. racemosa Lam., and $C$. australis that has been considered in literature as having globose endocarps does not differ significantly in the SL/SW ratio from species possessing compressed endocarps, i.e., C. alba L., C. sericea L., and C. occidentalis (Torr. \& A.Gray) Coville. However, C. alba differs significantly from $C$. sericea in this trait ( $t$ test $=5.24, d f=501, P<0.001)$. The mean value of the ratio is 1.0 [SD \pm 0.25$]$ for $C$. alba, whereas endocarps of $C$. sericea are wider than they are long (0.89 $[\mathrm{SD} \pm 0.15])$. A significant difference in SL/SW also was detected between $C$. sericea and $C$. occidentalis ( $t$ test $=$ $-4.55, d f 350, P<0.001$ ) while no difference was found between $C$. alba and $C$. occidentalis ( $t$ test $=0.89$, $d f=397, P<0.37)$. A significant difference between the sample means also was found between closely related C. amomum Mill. and C. obliqua ( $t$ test $=-4.40$, 


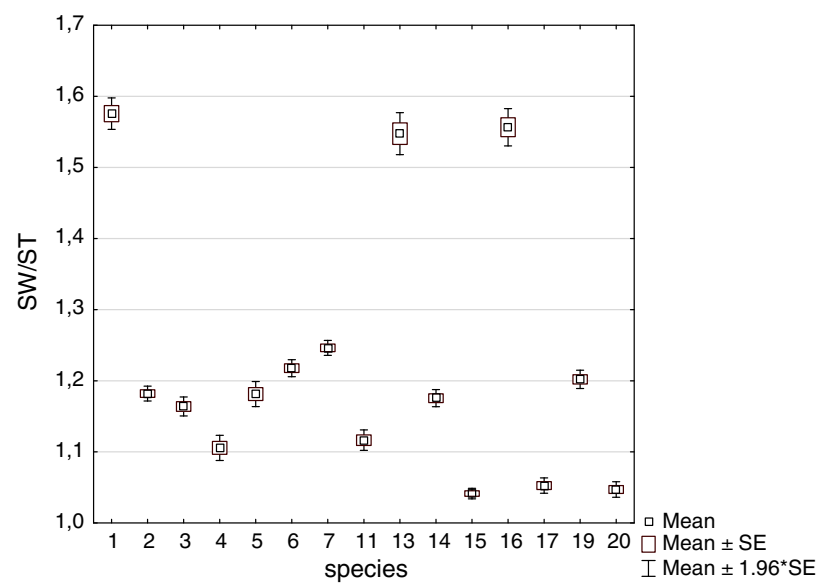

Fig. 8 Box-and-whisker plot for the ratio between endocarp width and endocarp thickness (SW/ST) in 15 Cornus species. For names of species, see Table 7

$d f=385, P<0.001)$. The highest SL/SW mean of all analyzed species was obtained for $C$. obliqua (1.04 [SD \pm 0.15$], n=181$ ), (Fig. 7).

The separation by PC 3, which was $15.61 \%$ of total variance, was caused by the ratio between endocarp width and endocarp thickness (SW/ST). This ratio gives an overall indication of the degree of an endocarp's flatness. As with the SL/SW ratio, the difference between subg. Mesomora and subg. Kraniopsis was insignificant, whereas a significant difference was noted between the group of species with globose endocarps and the group with compressed endocarps ( $t$ test $=-12.56, d f=98, P<0.0001$ ).

However, the SW/ST ratio allowed us to separate a group of species (C. alba, C. occidentalis, and C. sericea), that do not differ significantly $\left(F_{(2624)}=1.16, P=0.31\right)$ from the other species $(t$ test $=69.21, d f=2,810$, $P<0.001)$. The mean value for the first group of species (C. alba, C. occidentalis, and C. sericea) was higher (1.56 $[\mathrm{SD} \pm 0.19])$ than for the remaining species $(1.14$ [SD \pm 0.11]), (Fig. 8).

The analysis of the Tuckey post hoc HSD test (unequal $N$ ) and all quantitative traits (Table 7) revealed a significant separation between:

(i) all species belonging to subg. Kraniopsis and black-fruited species in subg. Mesomora (C. alternifolia and C. controversa);

(ii) C. alternifolia and C. controversa;

(iii) different morphological groups within subg. Kraniopsis, i.e., 5-7-veined species (C. alba, C. bretschneideri) and 3-4-veined species (C. australis, C. sanguinea, C. walteri), and between the first group and clavate-styled species (C. amomum or C. obliqua);
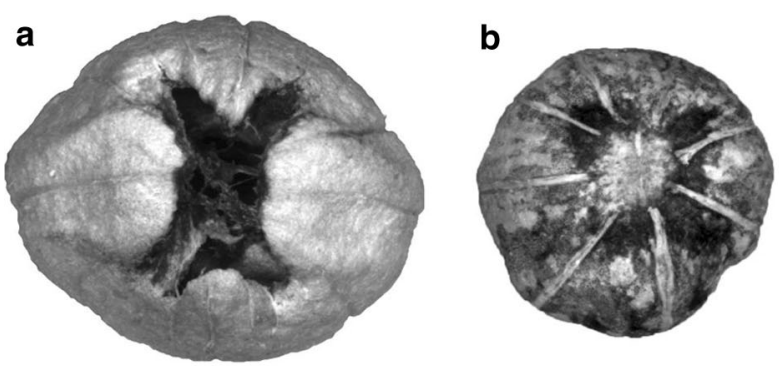

c

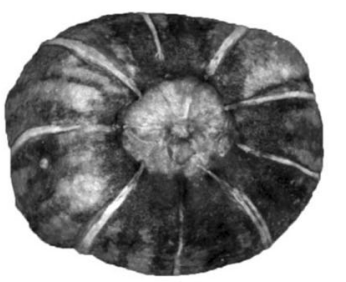

d

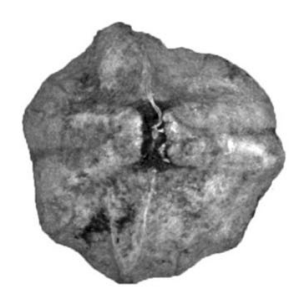

e

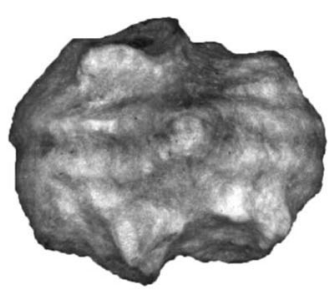

f

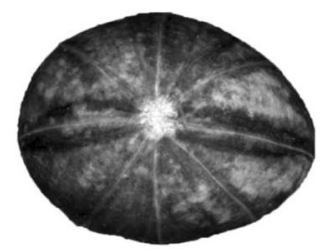

9

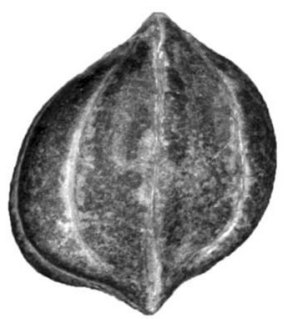

h

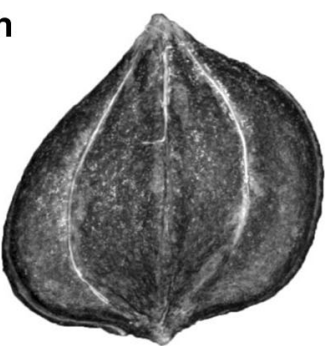

Fig. 9 Endocarps of North American species (×7.2): a Cornus alternifolia, u; b C. racemosa, u; c C. foemina, u; d C. obliqua, u; e $C$. amomum, $\mathrm{u} ; \mathbf{f}$ C. drummondii, b; g. C. sericea, $\mathrm{f} ; \mathbf{h}$ C. occidentalis, $\mathrm{f}$ ( $\mathrm{u}$, upper view; $\mathrm{b}$, bottom view; $\mathrm{f}$, front view)

(iv) clavate-styled (C. amomum, C. australis, $C$. walteri) and white-fruited (C. drummondii C.A.Mey, C. foemina, and C. racemosa);

(v) three- to four-veined $C$. sanguinea and whitefruited (C. drummondii, C. occidentalis, and $C$. racemosa).

On the other hand, the results revealed no significant differences in endocarp traits between, for example, North American white- or light blue-fruited species ( $C$. drummondii, C. foemina, C. racemosa, ) and clavate-styled species ( $C$. macrophylla and $C$. obliqua), $C$. sericea s.l. (including $C$. occidentalis), and five- to seven-veined $C$. bretschneideri. Moreover, no significant difference was detected between Eurasian white-fruited C. alba and North American white-fruited (C. foemina, C. racemosa, and 
C. drummondii). Besides, C. macrophylla does not differ from the majority of analyzed species of subg. Kraniopsis except $C$. amomum (Table 7).

Summing up, based on quantitative traits, it was possible to distinguish species belonging to subg. Mesomora from those in subg. Kraniopsis. We found that variation regions of species representing the latter subgenus overlapped, and only groups of species can be unambiguously identified.

To find associations between qualitative traits and species assignment, the Chi square test was performed based on the wild, cultivated, or combined data set. All analyses yielded congruent results. A significant association was

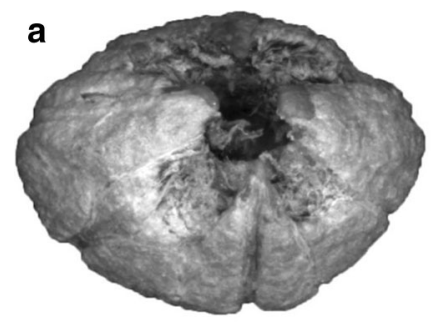

b

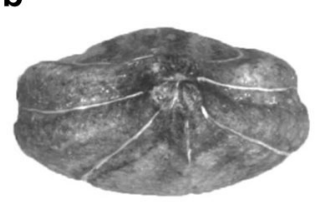

C
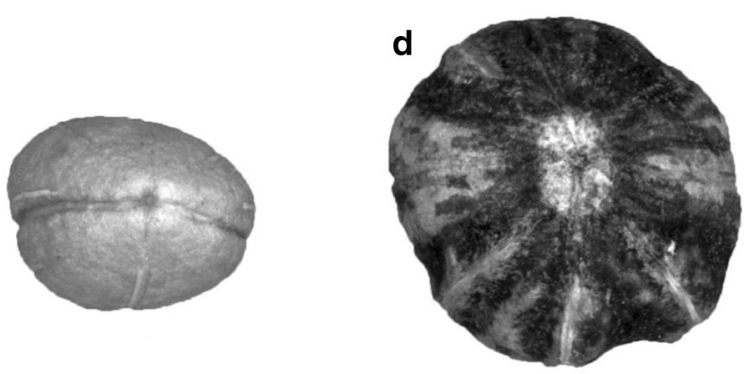

Fig. 10 Endocarps of Eurasian species (upper view, $\times 8.5$ ): a Cornus controversa; b C. alba; c C. bretschneideri, d C. australis found between species assignment and analyzed traits. The results also were broadly similar when only species of subg. Kraniopsis were evaluated (Table 8). A significant association was found between species recognition and a vascular bundle position (VBP) on the endocarp surface. This trait is positively correlated with endocarp surface ribbing pattern. Combining these two traits, it was possible to identify three groups of species based on the analyzed material: (1) sharply ribbed with raised vascular bundles running along crests of ribs (C. amomum, $C$. obliqua), (2) ribbed with sunken vascular bundles running in grooves $(C$. alternifolia, $C$. controversa), and (3) group with relatively smooth surface (remaining species).

Besides vascular bundles position on endocarp surface also their continuity or branching may differ particular

Table 8 Results of Chi square test for independence between qualitative traits of endocarps and species assignment, (1) species of subg. Mesomora and Kraniopsis, (2) species of subg. Kraniopsis, based on combined data set (cultivated and wild materials)

\begin{tabular}{|c|c|c|c|c|c|c|}
\hline \multirow{2}{*}{$\begin{array}{l}\text { Subgenus } \\
\text { Trait }\end{array}$} & \multicolumn{3}{|l|}{1} & \multicolumn{3}{|l|}{2} \\
\hline & $d f$ & Chi square & $P$ & $d f$ & Chi square & $P$ \\
\hline VBP & 28 & 370.00 & 0.00 & 12 & 159.00 & 0.00 \\
\hline SSH & 28 & 206.26 & 0.00 & 24 & 179.46 & 0.00 \\
\hline ASH & 42 & 133.79 & 0.00 & 36 & 109.31 & 0.00 \\
\hline $\mathrm{ACP}$ & 14 & 124.68 & 0.00 & 12 & 17.91 & 0.12 \\
\hline SSF & 14 & 123.69 & 0.00 & 12 & 119.58 & 0.00 \\
\hline BSH & 42 & 100.39 & 0.00 & 36 & 86.16 & 0.00 \\
\hline DF & 14 & 71.86 & 0.00 & 12 & 56.03 & 0.00 \\
\hline FV & 14 & 45.48 & 0.00 & 12 & 36.23 & 0.00 \\
\hline
\end{tabular}

Level of significance $P<0.05$; for trait descriptions, see Table 2
Table 7 Results of the Tukey test based on mean values of quantitative traits of endocarps for 185 specimens representing 15 Cornus species (subg. Mesomora and Kraniopsis)

Level of significance $P<0.05$. Species: 1: C. alba, 2: $C$. alternifolia, 3: C. amomum, 4: C. australis, 5: $C$. bretschneideri, 6: $C$. controversa, 7: C. drummondii, 11: C. obliqua, 13: $C$. occidentalis, 14: C. racemosa, 15: C. sanguinea, 16: $C$. sericea, 17: C. walteri, 19: $C$. foemina, 20: C. macrophylla

\begin{tabular}{|c|c|c|c|c|c|c|c|c|c|c|c|c|c|c|c|}
\hline & 1 & 2 & 3 & 4 & 5 & 6 & 7 & 11 & 13 & 14 & 15 & 16 & 17 & 19 & 20 \\
\hline 1 & $*$ & & & & & & & & & & & & & & \\
\hline 2 & $X$ & $*$ & & & & & & & & & & & & & \\
\hline 3 & $X$ & $X$ & $*$ & & & & & & & & & & & & \\
\hline 4 & $X$ & $X$ & & $*$ & & & & & & & & & & & \\
\hline 5 & & $X$ & $X$ & $X$ & $*$ & & & & & & & & & & \\
\hline 6 & $X$ & $X$ & $X$ & $X$ & $X$ & $*$ & & & & & & & & & \\
\hline 7 & & $X$ & $X$ & $X$ & & $X$ & $*$ & & & & & & & & \\
\hline 11 & $X$ & $X$ & & & $X$ & $X$ & & $*$ & & & & & & & \\
\hline 13 & & $X$ & $X$ & $X$ & & $X$ & & $X$ & $*$ & & & & & & \\
\hline 14 & & $X$ & $X$ & $X$ & & $X$ & & & & $*$ & & & & & \\
\hline 15 & $X$ & $X$ & & & $X$ & $X$ & $X$ & & $X$ & $X$ & $*$ & & & & \\
\hline 16 & & $X$ & $X$ & $X$ & & $X$ & & $X$ & & & $X$ & * & & & \\
\hline 17 & $X$ & $X$ & & & $X$ & $X$ & $X$ & & $X$ & $X$ & & $X$ & $*$ & & \\
\hline 19 & & $X$ & $X$ & $X$ & & $X$ & & & & & & & $X$ & $*$ & \\
\hline 20 & & $X$ & $X$ & & & $X$ & & & & & & & & & $*$ \\
\hline
\end{tabular}


species to some extent. The vascular bundles were not dichotomously forked (FV) in over $55 \%$ of endocarps of C. macrophylla and C. racemosa, whereas the opposite tendency was noted in the remaining species. In $C$. alternifolia, C. controversa, C. amomum, C. bretschneideri, C. obliqua, C. sanguinea, and C. walteri, only up to $10 \%$ of endocarps had continuous bundles. In C. alba, C. australis, C. drummondii, C. foemina, C. occidentalis, and $C$. sericea, this percentage ranged from 12.14 to $39.84 \%$.

The examined Cornus species are classified into three groups based on a visual judgment of endocarp shape (SSH): those with a spherical $=$ globose shape (e.g. $C$. walteri, C. macrophylla, C. sanguinea, C. racemosa, and, to a lesser extent $C$. obliqua, $C$. australis, $C$. alternifolia and $C$. controversa), a laterally flattened shape (C. alba and $C$. sericea including $C$. occidentalis), and ones in between (rest of species).

The majority of endocarps of C. alba, C. amomum, and C. obliqua are characterized by a shortly acuminate apex (ASH), whereas almost all the endocarps of the remaining species have either a rounded or truncated apex. Cornus sericea including $C$. occidentalis have either an acuminate or rounded apex. The basal portion of endocarps varies; for example, in $C$. alba rounded or long-acuminate bases can be observed, whereas in $C$. sericea either short acuminate or rounded bases can be noted. In other closely related taxa, no differences in the basal (and apical) portions of endocarps have been found (e.g., C. sanguinea and C. australis, or $C$. racemosa and C. foemina).

A distinctive furrow (DF) running longitudinally on the lateral faces of an endocarp can be found in $C$. sericea, $C$. occidentalis, and sometimes, C. alba and C. bretschneideri. The endocarps of remaining species are not so distinctly furrowed on the sides.

Is there a correspondence between different geographical groups of Cornus species and grouping based on endocarp traits?

The one-way MANOVA analysis was also performed based on PC scores (see Table 6) with geographic origin of species as a categorical variable. The MANOVA revealed a significant multivariate effect for the geographic origin (Wilks' lambda $\left.=0.94, F_{(3,181)}=4.05, P<0.01\right)$. The statistically significant separation among geographical groups occurs along PCA axis $3\left(F_{(1,183)}=11.14\right.$, $P<0.01)$. The highest loading for the PC 3 had the ratio between endocarp width and endocarp thickness (SW/ST) (Table 6, Online Resource 5, 6). Generally, the mean value of SW/ST for specimens representing species native to North America $(n=93)$ was higher (1.27, [SD \pm 0.15$])$ than those species native to Eurasia $(n=92 ; 1.18$ $[\mathrm{SD} \pm 0.23])$.
Table 9 Results of Chi square test for independence between qualitative traits of endocarps and species origin (North American/Eurasian) based on cultivated, wild and combined set of data; upper line: species of subg. Mesomora and Kraniopsis; bottom line: species of subg. Kraniopsis

\begin{tabular}{|c|c|c|c|c|c|c|c|}
\hline \multirow[b]{2}{*}{ Trait } & \multirow[b]{2}{*}{$d f$} & \multicolumn{2}{|c|}{ Cultivated (c) } & \multicolumn{2}{|c|}{ Wild (w) } & \multicolumn{2}{|c|}{ All $(\mathrm{c}+\mathrm{w})$} \\
\hline & & $\begin{array}{l}\text { Chi } \\
\text { square }\end{array}$ & $P$ & $\begin{array}{l}\text { Chi } \\
\text { square }\end{array}$ & $P$ & $\begin{array}{l}\text { Chi } \\
\text { square }\end{array}$ & $P$ \\
\hline \multirow[t]{2}{*}{ VBP } & \multirow{2}{*}{$\begin{array}{l}2 \text { all; } \\
1 \mathrm{c}\end{array}$} & 10.12 & 0.01 & 11.30 & 0.00 & 22.23 & 0.00 \\
\hline & & 9.97 & 0.00 & 11.20 & 0.00 & 22.03 & 0.00 \\
\hline \multirow[t]{2}{*}{$\mathrm{ASH}$} & \multirow[t]{2}{*}{3} & 8.53 & 0.04 & 3.75 & 0.29 & 9.36 & 0.02 \\
\hline & & 8.53 & 0.04 & 3.66 & 0.30 & 9.23 & 0.03 \\
\hline \multirow[t]{2}{*}{$\mathrm{ACP}$} & \multirow[t]{2}{*}{1} & 2.92 & 0.09 & 1.48 & 0.22 & 3.45 & 0.06 \\
\hline & & 3.95 & 0.05 & 3.69 & 0.05 & 6.10 & 0.01 \\
\hline \multirow[t]{2}{*}{ SSH } & \multirow[t]{2}{*}{2} & 8.16 & 0.02 & 29.65 & 0.00 & 34.91 & 0.00 \\
\hline & & 9.95 & 0.01 & 31.39 & 0.00 & 38.60 & 0.00 \\
\hline \multirow[t]{2}{*}{ SSF } & \multirow[t]{2}{*}{1} & 1.32 & 0.25 & 0.33 & 0.56 & 1.81 & 0.18 \\
\hline & & 3.34 & 0.07 & 4.89 & 0.03 & 9.00 & 0.00 \\
\hline \multirow[t]{2}{*}{$\mathrm{FV}$} & \multirow[t]{2}{*}{1} & 3.46 & 0.06 & 0.93 & 0.33 & 0.41 & 0.52 \\
\hline & & 3.28 & 0.07 & 1.02 & 0.31 & 0.33 & 0.56 \\
\hline \multirow[t]{2}{*}{ DF } & \multirow[t]{2}{*}{1} & 2.45 & 0.12 & 3.17 & 0.07 & 6.20 & 0.01 \\
\hline & & 2.24 & 0.13 & 3.09 & 0.08 & 6.02 & 0.01 \\
\hline \multirow[t]{2}{*}{$\mathrm{BSH}$} & \multirow[t]{2}{*}{3} & 0.72 & 0.87 & 17.09 & 0.00 & 11.67 & 0.01 \\
\hline & & 0.91 & 0.82 & 15.62 & 0.00 & 13.57 & 0.00 \\
\hline
\end{tabular}

Level of significance $P<0.05$; for trait descriptions, see Table 2

The Chi square test between qualitative traits and the origin of species belonging to subg. Mesomora and Kraniopsis, showed significant association for five traits $(P<0.05)$, whereas this association is insignificant for $\mathrm{FV}$, SSF, and ACP. When only specimens belonging to species of subg. Kraniopsis were analyzed, all traits except FV depended on the origin of specimens (Table 9). When only cultivated material was analyzed, only VBP, ASH, and $\mathrm{SSH}$ were significant, indicating that some qualitative traits depend on growing site.

In summation, the key for species identification based on endocarp traits was constructed on separate North American and Eurasian species data sets.

The second stage of the analysis examines endocarp measurements by dividing analyzed species as proposed by (Xiang et al. 2006). Based on parsimony analysis of mat $K$ sequences subg. Mesomora forms a sister clade to subg. Kraniopsis, which is divided into three subclades. This division reflects the current geographic partitioning of Cornus distribution space. Using PCA scores as dependent variables and the phylogenetic affinity of a species, as a categorical variable, the one-way MANOVA shows significant differences in traits among species representing considered clades and subclades (Wilks' lambda $=0.07$, $\left.F_{(3,9)}=70.11, P<0.001\right)$. The separation occurs along 
Table 10 Results of Chi-square test for independence between qualitative traits of endocarps and species affinity to phylogenetic clades (Xiang et al. 2006) based on cultivated, wild and combined set of data; upper line species of subg. Mesomora and Kraniopsis; bottom line species of subg. Kraniopsis

\begin{tabular}{|c|c|c|c|c|c|c|c|}
\hline \multirow[b]{2}{*}{ Trait } & \multirow[b]{2}{*}{$d f$} & \multicolumn{2}{|c|}{ Cultivated (c) } & \multicolumn{2}{|c|}{ Wild (w) } & \multicolumn{2}{|l|}{ All } \\
\hline & & $\begin{array}{l}\text { Chi } \\
\text { square }\end{array}$ & $P$ & $\begin{array}{l}\text { Chi } \\
\text { square }\end{array}$ & $P$ & $\begin{array}{l}\text { Chi } \\
\text { square }\end{array}$ & $P$ \\
\hline \multirow[t]{2}{*}{ VBP } & 6 & 85.57 & 0.00 & 109.74 & 0.00 & 196.42 & 0.00 \\
\hline & $\begin{array}{l}2 \text { all; } 4 \mathrm{c} ; \\
2 \mathrm{w}\end{array}$ & 21.16 & 0.00 & 25.29 & 0.00 & 47.41 & 0.00 \\
\hline \multirow[t]{2}{*}{$\mathrm{ASH}$} & 9 & 37.43 & 0.00 & 60.41 & 0.00 & 95.07 & 0.00 \\
\hline & 6 & 27.57 & 0.00 & 47.22 & 0.00 & 72.41 & 0.00 \\
\hline \multirow[t]{2}{*}{$\mathrm{ACP}$} & 3 & 35.27 & 0.00 & 63.21 & 0.00 & 95.92 & 0.00 \\
\hline & 2 & 1.83 & 0.40 & 4.43 & 0.11 & 4.21 & 0.12 \\
\hline \multirow[t]{2}{*}{ SSH } & 6 & 31.57 & 0.00 & 80.50 & 0.00 & 91.35 & 0.00 \\
\hline & 4 & 20.10 & 0.00 & 69.22 & 0.00 & 72.77 & 0.00 \\
\hline \multirow[t]{2}{*}{ SSF } & 3 & 22.34 & 0.00 & 18.59 & 0.00 & 38.93 & 0.00 \\
\hline & 2 & 21.16 & 0.00 & 18.10 & 0.00 & 40.59 & 0.00 \\
\hline \multirow[t]{2}{*}{ FV } & 3 & 20.45 & 0.00 & 3.43 & 0.33 & 11.00 & 0.01 \\
\hline & 2 & 14.61 & 0.00 & 0.82 & 0.66 & 4.71 & 0.09 \\
\hline \multirow[t]{2}{*}{ DF } & 3 & 8.06 & 0.04 & 13.54 & 0.00 & 17.71 & 0.00 \\
\hline & 2 & 2.56 & 0.28 & 9.80 & 0.01 & 9.62 & 0.01 \\
\hline \multirow[t]{2}{*}{$\mathrm{BSH}$} & 9 & 8.83 & 0.45 & 16.67 & 0.05 & 18.33 & 0.03 \\
\hline & 6 & 5.42 & 0.19 & 12.96 & 0.04 & 12.26 & 0.06 \\
\hline
\end{tabular}

Level of significance $P<0.05$; for trait descriptions, see Table 2

all three PCA axes $\left(F_{(3,134)}=129.04,19.09\right.$, and 17.72, respectively, $P<0.001)$.

A visualization of differences between specimens in PCA plots (Online Resource 7, 8) revealed that samples representing species belonging to subg. Mesomora are clearly separated from all other species. The highest loadings for PC 1 are ACL, ACW, and SW (Online Resource 9). Species included in subclade I (C. drummondii, $C$. foemina, $C$. racemosa) differ significantly in the ratio between endocarp length and endocarp width (SL/ $\mathrm{SW}$, highest loading for PC 2) from species included in subclade II ( $C$. amomum, C. obliqua, C. alba, and $C$. bretschneideri; $t$ test $=2.45, d f=70, P<0.02$ ). No significant difference was found between subclades II and III (C. macrophylla, C. sanguinea, and C. walteri).

The separation along PCA axis 3, which made up $13.96 \%$ of total variance, was caused predominantly by endocarp length and the ratio between endocarp width and thickness (SW/ST). A significant difference in endocarp length was found between subclades I and II ( $t$ test $=$ $-3.89, d f=70, P<0.001$ ), whereas the remaining comparisons within subg. Kraniopsis were insignificant.

The Chi-square test based on all accessions between qualitative traits and species assignment to phylogenetic subclades showed a significant relationship for all analyzed traits, $(P<0.05)$ (Table 10). These results were congruent with Chi-square tests based on either wild or cultivated materials, with some exceptions (Table 10). The Chisquare tests gave higher $P$ values when species of subg. Mesomora were excluded from the analysis, but for the majority of traits, the associations were still significant. For cultivated and wild specimens, ACP became insignificant.

\section{Discussion}

Considering that morphological continuity or instability might not be sufficient in determining species boundaries (e.g. Davis and Nixon 1992; Wiens and Servedio 2000; Sites and Marshall 2004), we did not strive to attain such a goal based on analyzed Cornus endocarp traits. Rather, we re-evaluated the taxonomic significance of these traits in the frame of widely accepted Cornus species, which were identified using other morphological traits (Koehne 1903; Wangerin 1910; Pylypenko 1960; Rehder 1967; Bean 1970; Eyde 1988; Cullen et al. 1997; Xiang and Boufford 2005; Schulz 2011, 2012).

Koehne (1896, after Schulz 2011) underlined for the first time an importance of apical cavity in the Cornus classification, particularly in the discrimination between subgenera (Mesomora and Kraniopsis). A very noticeable apical cavity is characteristic for the species belonging to subg. Mesomora, whereas a less conspicuous one, sometimes called an apical depression, is attributed to species representing subg. Kraniopsis. Other authors followed this view, e.g., Eyde (1988), Xiang and Boufford (2005), and Schulz (2011, 2012). Within subg. Kraniopsis, the apical depression has been described very rarely, and only for $C$. sanguinea (Eyde 1987, 1988), C. macrophylla (Koehne 1903; Schulz 2012), C. атотиm (Wangerin 1910), and one East Asian Cornus taxon (Xiang and Boufford 2005). Our study confirms the previous findings related to the subgenera delimitation based on this trait and contributes additional evidence that the apical depression may be found in $C$. sanguinea, $C$. australis, $C$. bretschneideri, $C$. foemina, C. macrophylla, C. obliqua, and C. walteri. The compelling evidence that such depression is present on the surface of $C$. amomum endocarp is not provided by our study.

Variations in the shape of endocarps can be helpful in the Cornus species identification. In $C$. alternifolia, $C$. controversa, C. racemosa, and C. australis, endocarps described as globose have been observed (Xiang and Boufford 2005; Bojňanský and Fargašová 2007; Schulz 2012), whereas in C. alba, C. sericea, and C. occidentalis, compressed endocarps have been noticed (Wangerin 1910; Fosberg 1942; Rehder 1967; Xiang and Boufford 2005; 
Bojňanský and Fargašová 2007; Schulz 2012). Nevertheless, for the majority of taxa, various terms are used to describe endocarp shapes, and these sometimes have been incorporated into keys buildup to identify Cornus species. For example, endocarps of $C$. bretschneideri are described as globose (Koehne 1903), ovoid-globose (Xiang and Boufford 2005), or slightly compressed (Schulz 2012); $C$. sanguinea as globose (Schulz 2012) or ovoid-globose (Bojňanský and Fargašová, 2007); and C. foemina as globose (Koehne 1903; Schulz 2012) or subglobose (Wilson 1965). Two extremes, i.e., taxa with the globose endocarps and those with compressed endocarps, differ significantly in the width/thickness ratio. Thus, this ratio is considered here as a key trait. However, both ratio(s) (SL/SW and SW/ ST) and arbitrary cutoffs (globose, intermediate and compressed endocarps; trait SSH, Table 2), applied to express the endocarp shape, do not allow classification of all examined specimens into clearly defined, non-overlapping groups.

Both ratios (SL/SW and SW/ST), however, could be used to distinguish between endocarps of $C$. alba and $C$. sericea. According to several authors (Rehder 1967; Seneta 1994; Xiang and Boufford 2005; Bojňanský and Fargašová 2007; Schulz 2012), C. alba endocarps are laterally compressed, which is also confirmed by our study. C. alba and $C$. sericea differ significantly in both ratios, also in the case when $C$. occidentalis is included to the analysis. However, no significant differences in these traits were detected between specimens originally labeled as $C$. occidentalis and $C$. alba or between $C$. occidentalis and C. sericea. A close relationship between $C$. sericea and $C$. occidentalis was observed in the other quantitative traits of endocarps, suggesting that they should not be treated as distinct species. Not significantly different values of the SW/ST ratio also support a close relationship of $C$. foemina and $C$. racemosa (Wilson 1965; Schulz 2012), and C. sanguinea and C. australis (Ball 2005; Schulz 2012).

Moreover, considerable variability in qualitative traits has also been observed within a particular taxon. For example, the endocarp base of $C$. sericea is described as rounded (Wangerin 1910; Rehder 1967; Seneta 1994) or truncated (Bojňanský and Fargašová 2007), whereas in $C$. $a l b a$, it is described as cuneate (Wangerin 1910; Ball 2005), acute (narrowed) (Rehder 1967; Seneta 1994) or obtuse and acuminate (Bojňanský and Fargašová 2007). Here, a statement made by Eyde (1988) is agreed upon, which is "Some (endocarps) of C. sericea and C. alba do not, however, conform to that distinction" (cuneate vs. rounded), (Eyde 1988: 285). The endocarps of C. occidentalis mainly have a bluntly acute or wedge-shaped base, which is in agreement with Koehne (1903). This taxon can be identified by its short acuminate apex, contrary to $C$. sericea, which more often has a rounded or truncated apex. This close relationship between $C$. sericea, $C$. alba and $C$. occidentalis was previously noted by Fosberg (1942), who treated C. occidentalis at the rank of subspecies in the combination $C$. sericea ssp. occidentalis, and Schulz (2012), who treated it at the rank of variety below subspecies stolonifera of $C$. alba. The taxonomic level of $C$. occidentalis is difficult to assess based on endocarp structure, and more detailed studies are needed. Provisionally, this taxon is considered as a subspecies of C. sericea. Other pairs of closely related species, such as Cornus racemosa-C. foemina and $C$. sanguinea-C. australis, do not differ in the apical and basal portions. In the latter case, based on all endocarp characteristics, a conclusion of Schulz (2012) is supported that $C$. australis should be reduced to the status of subspecies within $C$. sanguinea.

Another feature that may differentiate closely related Cornus species is a diverse surface sculpturing pattern (Wangerin 1910; Fosberg 1942; Wilson 1965; Eyde 1988; Schulz 2011, 2012). However, there is much confusion in the literature concerning the terminology used to describe it. The term "furrow" applied in this study follows Fosberg (1942), but Bojňanský and Fargašová (2007) used the phrase "longitudinal furrows" to define structures observed on the whole outer surface of the endocarp. In our opinion, this probably should be related to vascular bundles. Some researchers interpreted broadly the endocarp sculpturing and used different terms such as "ridged," "ribbed," and "grooved" (Koehne 1903; Wangerin 1910; Fosberg 1942; Xiang and Boufford 2005; Bojňanský and Fargašová 2007), sometimes synonymously (Wilson 1965). The ribs and grooves are formed in the early stages of fruits development as a wavy layer of cells between the mesocarp and the endocarp. In a final stage of the development, this wavy line of cells corresponds to the ribs and grooves present on the endocarp surface (Kaniewski and Hausbrandt 1968).

Some problems with terminology lead to difficulties in recognizing, comparing, and interpreting taxa. Reports of Wilson (1965) and Xiang and Boufford (2005) cannot be directly interpreted here because they refer to occurrences of ridges, ribs, or grooves. However, taking into account smooth/rough surface, we support the view that $C$. bretschneideri and $C$. walteri, described as "inconspicuously ribbed" (Xiang and Boufford 2005), and $C$. sericea $(=C$. stolonifera Michx.), C. drummondii and C. foemina characterized as "not grooved" (Wilson 1965), have a smooth surface with flat vascular bundles. The presence of a conspicuous irregular ribbing pattern and variable vascular bundles observed on $C$. amomum and $C$. obliqua endocarps indicate a great similarity of these taxa and support the conclusion of Schulz (2012) that C. obliqua should be reduced to the status of subspecies within $C$. amomum. 
We are also able to confirm the occurrence of a distinctive furrow on C. occidentalis endocarps (Fosberg 1942). Moreover, we noted that a distinctive furrow also occurs on C. sericea endocarps and, to a lesser extent, on C. alba and $C$. bretschneideri endocarps, which is in agreement with Schulz (2012, p. 111, Abb. 42).

In sum, the applicability of our results to the previously published records is limited, mainly because not all aspects of the endocarp structure were studied with the same level of detail, as in the published records and the vague terminology.

More recently, literature has emerged that offers additional findings about the species level phylogeny of the genus Cornus based on molecular and morphological evidence (Xiang et al. 2006). The concept of species within Cornus, particularly within the black- or white-fruited dogwoods, has been challenged by this study. Within the BW group, subg. Kraniopsis is highly diverse, having both North American and Asian species. There are species composition inconsistencies between subclades distinguished within subg. Kraniopsis depending on the considered DNA region. On the other hand, subg. Mesomora is a stable sister clade to subg. Kraniopsis (Xiang et al. 2006).

Our results provided support for the molecular inferences in several ways. First, in all analyses of endocarp traits, a clear separation between species of subg. Mesomora and species of subg. Kraniopsis is clearly visible. In addition, there are significant differences in quantitative and qualitative traits between species representing different subclades (I-III) within the Kraniopsis clade. We observed no significant differences between species belonging to a particular subclade (e.g., C. drummondii, C. foemina, and C. racemosa).

However, this congruence is only partial, and there are still many inconsistencies. Grouping based on presumably neutral molecular markers (Xiang et al. 2006) is unlikely to predict accurately patterns of variation in quantitative traits because natural selection is the primary force on the traits (e.g., Pemberton 2010). Some observed inconsistencies may be explained by saturation in morphological character states, e.g., due to adaptive convergence (homoplasy), developmental and functional constraints, but also saturation in DNA substitutions, hybridization leading to genetic admixture and intermediate morphology, different taxonomic sampling, and algorithms/models being used (e.g., Phillips et al. 2004; Dávalos et al. 2012).

We expected that relaxed selective pressures in culture conditions on quantitative traits increase their variance (e.g. Miller and Knouft 2006, see also Rajon and Plotkin 2012 and references therein). This was not the case. It can be explained by the non-genetic carryover effect of the parent environment and an organism's short-time exposure to a new selective pressure or a weak-if any-selective pressure on these traits in wild and cultured conditions (Bonduriansky and Day 2009).

We found also that wild and cultivated specimens of Cornus species significantly differ in qualitative endocarp traits in subg. Kraniopsis, which may indicate the ability to adapt to varied conditions or reflect random changes. Given the restrictions of this current study, further experimental investigations are needed to determine if these differences in qualitative or quantitative traits have a genetic basis, e.g., through defined crosses in QTL analysis.

Finally, a number of important limitations need to be considered. In spite of the fact that no research in Cornus studies has surveyed an endocarp data set so large and complex as the one considered here, sampling is one of the major factors influencing our results. Limited availability of fruits and a restricted spatial distribution of studied accessions for some species make well-founded generalizations difficult.

Here, some of the analyzed qualitative and quantitative endocarp traits partially overlap. Because subjectivity may affect qualitative traits analysis, cross-checking one data set against another (quantitative) becomes meaningful. On the other hand, individual experiences can be used in species identification, which create separate results for qualitative data.

\section{Conclusion}

The morphology of Cornus endocarps is of taxonomic importance and provides a key for species identification. The existence of only subtle morphological differences in endocarps between some closely related taxa does not sufficiently explain their species status. Nevertheless, the applicability of our results to the previously published morphological records is limited, mainly due to vague terminology. Significant differences in endocarp traits were found for different geographical partitioning of the Cornus distribution space. Considerably more work needs to be done to determine the effect of cultivation on qualitative reproductive traits of Cornus species. This work is continued by analyzing the internal structure of endocarps in Cornus species.

A dichotomous key for Cornus species native to North America and Eurasia

Measurements of quantitative traits of endocarp (its length $\times$ width, thickness): mean or/and range in (mm). A graphical description of endocarp's traits is given in Fig. 3. Abbreviation: endocarp - 'e' 
Species native to North America

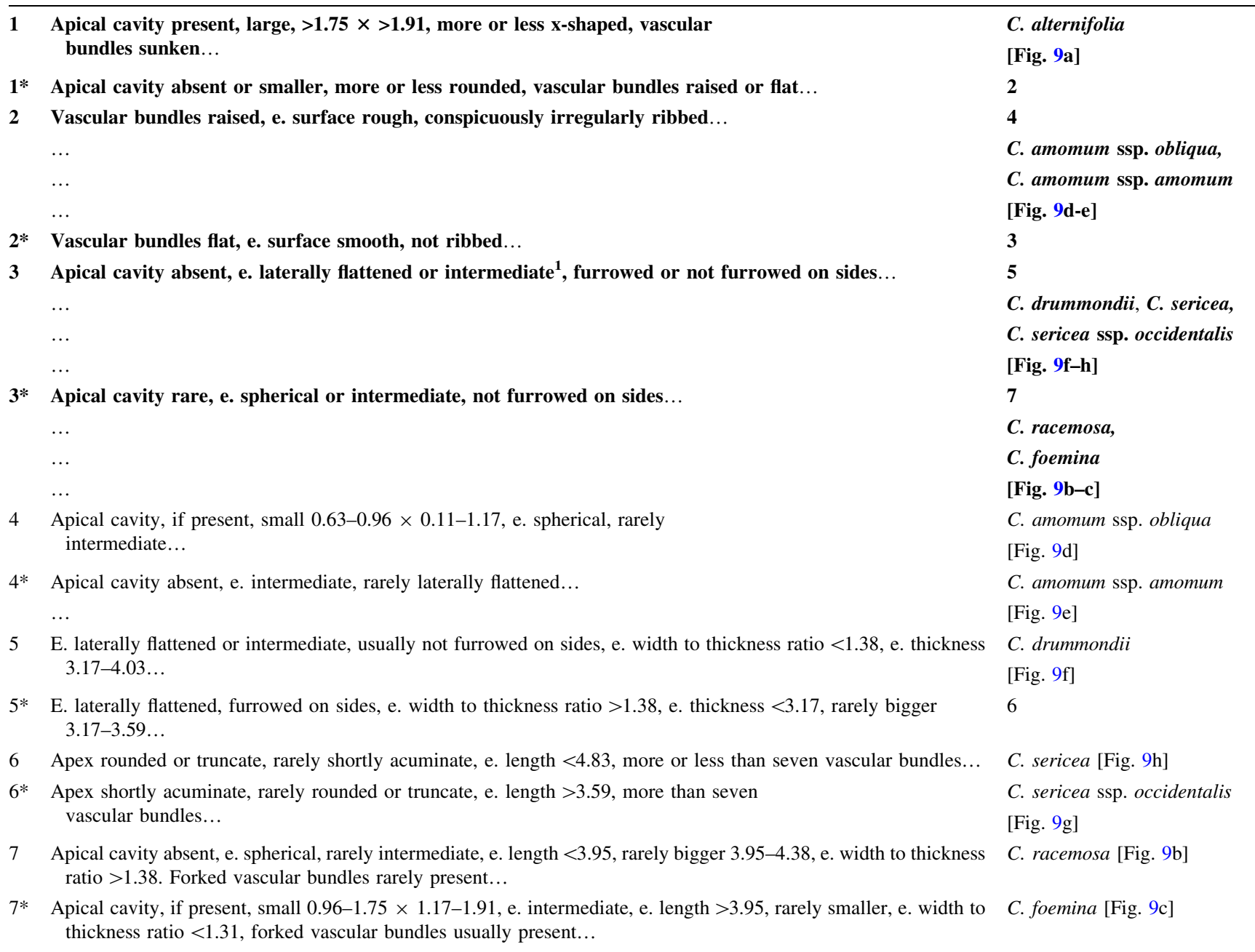

${ }^{1}$ Endocarp shape intermediate between flattened and spherical

Species native to Eurasia

$1 \quad$ Apical cavity present, large, $>1.22 \times>1.59$, more or less $x$-shaped, vascular bundles $C$. controversa sunken...

1* Apical cavity absent or smaller, more or less rounded, vascular bundles flat...

2 E. laterally flattened or intermediate ${ }^{1}$, furrowed on sides...

$\cdots$

2* E. spherical, rarely intermediate, not furrowed on sides...

$\ldots$

$\cdots$

$\cdots$

3 Apical cavity absent, e. flattened or intermediate, e. width $>3.81$, apex usually shortly acuminate, base rounded or long-acuminate...

3* Apical cavity, if present, small $0.08-0.67 \times 0.12-0.65$, e. usually intermediate, e. width $<3.58$, apex usually acuminate, base bluntly acute or wedge-shaped..
[Fig. 10a]

2 [Fig. 10b-d]

3

C. alba, C. bretschneideri [Fig. 10b-c]

4

C. macrophylla, C. sanguinea ssp. sanguinea,

C. sanguinea ssp. australis, $C$. walteri

[Fig. 10d]

C. alba [Fig. 10b]

C. bretschneideri

[Fig. 10c] 
continued

\begin{tabular}{|c|c|c|}
\hline 4 & $\begin{array}{l}\text { Apical cavity, if present, small } 0.67-1.22 \times 0.89-1.59 \text {, e. length }<4.16 \text {, } \\
\text { rarely bigger } 4.16-5.35 \text {, e. thickness }<4.35 \text {, forked vascular bundles rarely present... }\end{array}$ & C. macrophylla \\
\hline $4^{*}$ & $\begin{array}{l}\text { Apical cavity, if present, small } 0.67-1.22 \times 0.65-0.89 \text {, e. length }<4.16 \text {, } \\
\text { rarely bigger } 4.16-5.35 \text {, e. thickness }>3.71 \text {, forked vascular bundles always present... }\end{array}$ & C. sanguinea ssp. sanguinea \\
\hline $4 * *$ & $\begin{array}{l}\text { Apical cavity, if present, small } 0.67-1.22 \times<0.65-1.59 \text {, e. length }>4.16 \text {, } \\
\text { e. thickness }>4.35 \text {, rarely smaller } 3.71-4.35 \text {, forked vascular bundles always present... }\end{array}$ & C. sanguinea ssp. australis [Fig. 10d] \\
\hline $4 * * *$ & $\begin{array}{l}\text { Apical cavity, if present, small } 0.08-0.67 \times 0.12-0.65 \text {, e. length }>4.16 \text {, } \\
\text { rarely smaller, e. thickness }>4.35 \text {, rarely smaller } 3.48-4.35 \text {, forked vascular } \\
\text { bundles usually present... }\end{array}$ & C. walteri \\
\hline
\end{tabular}

${ }^{1}$ Endocarp shape intermediate between flattened and spherical

Acknowledgments We would like to thank the following arboreta, botanical gardens: Adam Mickiewicz University Botanical Garden in Poznań, PL; Armand David Botanical Garden, FR; Bolestraszyce Arboretum, PL; Botanic Garden of Maria Curie-Skłodowska University, PL; Botanic Garden of the Jagiellonian University, PL; Botanical Garden and Botanical Museum Berlin-Dahlem, GE; Botanical Garden Ljubljana, SI; Dendrological Garden in Glinna, PL; Dendrological Garden of University of Life Sciences in Poznań, PL; Gołubie Botanical Garden, PL; Kórnik Arboretum, PL; Mustila Arboretum, FI; Research Center for Medicinal Plant Resources, Nat. Institute of Biomedical Innovation, JP; Sapienza University of Rome, IT; Tallin Botanical Garden, EE; The Amur branch of Botanical Garden-Institute, RU; The Arnold Arboretum of Harvard University, US; The Botanic Garden of Smith College Northampton, US; University of Salzburg, AT; Warsaw University of Life Sciences (SGGW) Rogów Arboretum, PL; Wirty Arboretum, PL; Wrocław University Botanical Garden, PL; and herbaria: A, BM, G, GH, H, K, KOR, KRAM, L, LISU, S, SZCZ, WA (Herbarium of Faculty of Biology, University of Warsaw) for loaning Cornus plant material. We would also like to extend our thanks to Wojciech Klimko from the Department of Botany for his technical assistance in preparation of figures. The authors thank the anonymous reviewers for their comments, which have helped to improve the manuscript.

Open Access This article is distributed under the terms of the Creative Commons Attribution License which permits any use, distribution, and reproduction in any medium, provided the original author(s) and the source are credited.

\section{References}

Anthony F, Combes M, Astorga C, Bertrand B, Graziosi G, Lashermes P (2002) The origin of cultivated Coffea arabica L. varieties revealed by AFLP and SSR markers. Theor Appl Genet 104:894-900

Ball PW (2005) Cornaceae. In: Tutin TG, Heywood VH (eds) Flora Europaea (Ninth printing), vol: 2. Rosaceae to Umbelliferae. Cambridge University Press, New York, p 313

Bean WJ (1970) Trees and shrubs. Hardy in the British Isles. John Murray, London

Bojňanský V, Fargašová A (2007) Atlas of seeds and fruits of central and east-European flora. Springer, Dordrecht

Bonduriansky R, Day T (2009) Nongenetic inheritance and its evolutionary implications. Annu Rev Ecol Evol Syst 40:103-125

Chang Y, Shi S, Zhao Ch, Han Z (2011) Characteristics of papillae in wild, cultivated and hybrid sea cucumbers (Apostichopus japonicus). Afr J Biotechnol 10:13780-13788
Cullen J, Alexander JCM, Brickell CD, Edmondson JR, Green PS, Heywood VH, Jørgensen P-M, Jury SL, Knees SG, Matthews VA, Maxwell HS, Miller DM, Nelson EC, Robson NKB, Walters SM, Yeo PF (1997) The European garden flora. A manual for the identification of plants cultivated in Europe, both out-of-doors and under glass. Dicotyledons (Part III), vol. V. University Press, Cambridge

Dávalos LM, Cirranello AL, Geisler JH, Simmons NB (2012) Understanding phylogenetic incongruence: lessons from phyllostomid bats. Biol Rev 87(4):991-1024

Davis JL, Nixon KC (1992) Populations, genetic variation, and the delimitation of phylogenetic species. Syst Biol 41:421-435

Eyde RH (1987) The case for keeping Cornus in the broad Linnaean sense. Syst Bot 12:505-518

Eyde RH (1988) Comprehending Cornus: puzzles and progress in the systematics of the dogwoods. Bot Rev 54(3):233-351

Eyde RH (1997) Fossil record and ecology of Nyssa (Cornaceae). The Bot Rev 63(2):97-114

Fan C, Xiang Q-Y (2001) Phylogenetic relationships within Cornus (Cornaceae) based on $26 \mathrm{~S}$ rDNA sequences. Am J Bot 88(6):1131-1138

Feng CM, Xiang Q-Y, Franks RG (2011) Phylogeny based developmental analyses illuminate evolution of inflorescence architectures in dogwoods (Cornus s.l., Cornaceae). New Phytol 191(3):850-869

Ferguson IK (1966) Notes on the nomenclature of Cornus. J Arnold Arbor 47:100-105

Fleming TH, Valiente-Banuet A (2002) Columnar cacti and their mutualists. evolution, ecology, and conservation. The University of Arizona Press, USA

Fosberg FR (1942) Cornus sericea L. (C. stolonifera Michx.). Bull Torrey Bot Club 69(8):583-589

Hardin JW, Murrell ZE (1997) Foliar micromorphology of Cornus. J Torrey Bot Soc 124(2):124-139

Howell DC (2007) Statistical methods for psychology, 6th edn. Thomson Wadsworth, Belmont

Hutchinson J (1942) Neglected generic characteristics in the family Cornaceae. Ann Bot (London), ser. 2. 6:83-93

Kaniewski K, Hausbrandt L (1968) Comparative investigations on the development of pericarp of some species of Cornus. Rocznik PTD 22:73-90 [in Polish]

Koehne E (1896) Über einige Cornus-Arten besonders C. macrophylla Wall. und C. corynostrylis n. sp. Gartenflora 45:236-239, 284-288

Koehne E (1903) Die Sektion Microcarpium der Gattung Cornus. Mitt Deutsch Dendrol Ges 12:27-50

Kubitzki K (2004) Cornaceae. In: Kubitzki K (ed) The Families and Genera of Vascular Plants, vol 6., Flowering plants: dicotyledons: Celastrales, Oxidales, Rosales, Cornales, Ericales. Springer, New York, pp 82-90

Macbride JF (1929) Cornus, a genus new to South America. Trop Woods 19:4-5 
Manchester SR, Xiang X-P, Xiang Q-Y (2010) Fruits of cornelian cherries (Cornaceae: Cornus subg. Cornus) in the Paleocene and Eocene of the Northern Hemisphere. Int $\mathbf{J}$ Plant Sci 171(8):882-891

Miller AJ, Knouft JH (2006) GIS-based characterization of the geographic distributions of wild and cultivated populations of the Mesoamerican fruit tree Spondias purpurea (Anacardiaceae). Am J Bot 93(12):1757-1767

Morozowska M, Woźnicka A, Kujawa M (2012) Microsturucture of fruits and seeds of selected species of Hydrangeaceae (Cornales) and its systematic importance. Acta Sci Pol Hortorum Cultus 11(4):17-38

Murrell ZE (1993) Phylogenetic relationships in Cornus (Cornaceae). Syst Bot 18(3):469-493

Murrell ZE (1996) A new section of Cornus in South and Central America. Syst Bot 21:273-288

Oh IC, Anderberg AL, Schönenberger J, Anderberg AA (2008) Comparative seed morphology and character evolution in genus Lysimachia (Myrsinaceae) and related taxa. Plant Syst Evol 271(3-4):177-197

Padgett DJ (2003) Phenetic studies in Nuphar Sm. (Nymphaeaceae): variation in sect. Nuphar. Plant Syst Evol 239:187-197

Paz L, Vázquez-Yanes C (1998) Comparative seed ecophysiology of wild and cultivated Carica papaya trees from a tropical rain forest region in Mexico. Tree Physiol 18:277-280

Pemberton JM (2010) Evolution of quantitative traits in the wild: mind the ecology. Phil Trans R Soc B 365:2431-2438

Phillips MJ, Delsuc F, Penny D (2004) Genome-scale phylogeny and the detection of systematic biases. Mol Biol Evol 21:1455-1458

Pojarkova A (1950) De systemate generis Linneani Cornus L. Bot. mater. Gerb Bot Inst Komarova Akad Nauk SSSR 12:164-180

Pylypenko FS (1960) Cornaceae. In: Sokolov SJa (ed) Derev'ja i kustarniki SSSR. 5. Akademii Nauk SSSR, Moskva-Leningrad, pp 200-237 [in Russian]

Rajon E, Plotkin JB (2012) The evolution of genetic architecture underlying quantitative traits. Eprint arXiv 1210:8423

Rehder A (1967) Manual of cultivated trees and shrubs. The MacMillan Co, New York

Ronse Decraene LP, Hong SP, Smets EF (2000) Systematic significance of fruit morphology and anatomy in tribes Persicarieae and Polygoneae (Polygonaceae). Bot J Linn Soc 134:301-337

Sárnal M, Kárný M, Benali H, Backfrieder W, Todd-Pokropek A, Bergmann H (1999) Experimental comparison of data transformation procedures for analysis of principal components. Phys Med Biol 44(11):2821-2834

Schulz B (2011) Die Gattung Cornus (Cornaceae), Hartriegel und Kornelkirsche, Teil 1 und 2. Mitt Deutsch Dendrol Ges 96:67-83

Schulz B (2012) Die Gattung Cornus (Cornaceae), Hartriegel und Kornelkirsche, Teil 3. Mitt Deutsch Dendrol Ges 97:91-132

Seneta W (1994) Drzewa i krzewy liściaste C. Wydawnictwo Naukowe PWN, Warszawa [in Polish]

Sites JW, Marshall JC (2004) Operational criteria for delimiting species. Annu Rev Ecol Evol Syst 35:199-227

Stevens PF (2012) Angiosperm Phylogeny Website. Version 12, July 2012 [and more or less continuously updated since]. http://www. mobot.org/MOBOT/research/APweb/
Tabachnick BG, Fidell LS (2007) Using multivariate statistics, 5th edn. Allyn \& Bacon, Boston

Takhtajan A (1997) Diversity and classification of flowering plants. Columbia University Press, New York

The Plant List (2010). Version 1. Published on the Internet. http:// www.theplantlist.org/. Accessed 1 Jan

Thiers B (continuously updated) Index Herbariorum: A global directory of public herbaria and associated staff. New York Botanical Garden's Virtual Herbarium. http://sweetgum.nybg. org/ih/

Toma C (2008) Carpological study of species of Alismatidae subclass (Helobiae ordo) occurring in Poland. Bogucki Scientific Publishers, Poznań. [in Polish with English summary]

Wang Q, Wei S, Wang W (2012) Comparative study of plant morphological characteristics and photosynthetic physiological characteristics of wild and cultivated Paeonia lactiflora. Zhongguo Zhong Za Zhi 37(1):32-36

Wangerin W (1910) Cornaceae. In: Engler A (ed) Das Pflanzenreich, ser. IV, fam. 229 (Heft 41). W. Engelmann, Leipzig

Wiens JJ, Servedio MR (2000) Species delimitation in systematics: inferring diagnostic differences between species. Proc Roy Soc Lond B 267:631-636

Wilson JS (1965) Variation of three taxonomic complexes of the genus Cornus in eastern United States. Trans Kansas Acad Sci 67:747-817

Xiang Q-Y (1987) A neglected character of Cornus L. s.l. with special reference to a new subgenus-Sinocornus Q.Y. Xiang. Acta Phytotax Sin 25:125-131

Xiang Q-Y (1989) Taxonomy of Cornus schindleri complex based on quantitative analysis of some characters. Bull Bot Res (Harbin) 9:125-138

Xiang Q-Y, Boufford DE (2005) Cornaceae. In: Wu ZY, Raven PH (eds) Flora of China, vol 14. Science Press and St. Louis: Missouri Botanical Garden, Beijing, pp 206-221

Xiang Q-Y, Soltis DE, Morgan DR, Soltis PS (1993) Phylogenetic relationships of Cornus L. sensu lato and putative relatives inferred from $r b c \mathrm{~L}$ sequence data. Ann Mo Bot Gard 80:723-734

Xiang Q-Y, Brunsfeld SJ, Soltis DE, Soltis PS (1996) Phylogenetic relationship in Cornus based on chloroplast DNA restriction sites: implications for biogeography and character evolution. Syst Bot 21:515-534

Xiang Q-Y, Soltis DE, Soltis PS (1998) Phylogenetic relationships of Cornaceae and close relatives inferred from mat $\mathrm{K}$ and $r b c \mathrm{~L}$ sequences. Am J Bot 85:285-297

Xiang Q-Y, Shui Y-M, Murrell Z (2003) Cornus eydeana (Cornaceae), a new cornelian cherry from China-notes on systematics and evolution. Syst Bot 28(4):757-764

Xiang Q-Y, Thomas DT, Zhang W, Manchester SR, Murrell Z (2006) Species level phylogeny of the genus Cornus (Cornaceae) based on molecular and morphological evidence-implications for taxonomy and Tertiary intercontinental migration. Taxon 55(1):9-30

Zarafshar M, Akbarinia M, Sattarian A (2010) Endocarp morphology of Iranian Celtis (Celtidaceae-Cannabaceae). Int J Plant Prod 4(1):73-78 